Research Paper

\title{
Anticancer Effects of Helminthostachys zeylanica Ethyl acetate Extracts on Human Gastric Cancer Cells through Downregulation of the TNF- $\alpha$-activated COX-2-cPLA2- $\mathrm{PGE}_{2}$ Pathway
}

Ming-Ming Tsai ${ }^{*}$, Horng-Chyuan Lin ${ }^{2 *}$, Ming-Chin $\mathrm{Yu}^{3}$, Wan-Jung Lin ${ }^{4}$, Mei-Yi Chu ${ }^{4}$, Ching-Ching Tsai ${ }^{5}$ and Ching-Yi Cheng $4,6 \bowtie$

1. Department of Nursing, Division of Basic Medical Sciences, Research Center for Chinese Herbal Medicine, College of Human Ecology, Chang Gung University of Science and Technology, Taoyuan, Taiwan and Department of General Surgery, Chang Gung Memorial Hospital at Chiayi, Chiayi, Taiwan.

2. Department of Thoracic Medicine, Chang Gung Memorial Hospital at Linkou and College of Medicine, Chang Gung University, Taoyuan, Taiwan.

3. Department of Surgery, New Taipei Municipal TuCheng Hospital, Chang Gung Memorial Hospital at Linkou, and College of Medicine, Chang Gung University, Taoyuan, Taiwan.

4. Graduate Institute of Health Industry Technology, Research Center for Chinese Herbal Medicine and Research Center for Food and Cosmetic Safety, College of Human Ecology, Chang Gung University of Science and Technology, Taoyuan, Taiwan.

5. Department of Nursing, College of Nursing, Chang Gung University of Science and Technology, and Department of Cardiology, Chang Gung Memorial Hospital at Linkou, Taoyuan, Taiwan.

6. Department of Pulmonary Infection and Immunology, Chang Gung Memorial Hospital at Linkou, Taoyuan, Taiwan.

*These authors have contributed equally to this work.

$\triangle$ Corresponding author: E-mail: jennycheng@mail.cgust.edu.tw (C.Y.C.); Telephone: 886-3-2118999 EXT. 5114/Fax: 886-3-2118866.

(C) The author(s). This is an open access article distributed under the terms of the Creative Commons Attribution License (https://creativecommons.org/licenses/by/4.0/). See http:/ /ivyspring.com/terms for full terms and conditions.

Received: 2021.07.06; Accepted: 2021.09.24; Published: 2021.10.17

\begin{abstract}
Background: Gastric cancer (GC) is the second most prevalent cancer worldwide and the eighth most common cause of tumor-related death in Taiwan. Helminthostachys zeylanica, a flavonoid compound, has anti-inflammatory, immunomodulatory, and anticancer effects. We examined whether an extract of $H$. zeylanica (E1 and E2) has potential as a treatment for GC.

Methods: We investigated the effects (pro-apoptosis, pro-autophagy, and antiproliferation ability) of $H$. zeylanica-E2 on cell viability in healthy gastric epithelial (GES-1) and GC cells (AGS and BGC823). $H$. zeylanica-E2 was toxic to GC cells but had little or no toxicity to normal cells.

Results: In this study, $\mathrm{H}$. zeylanica-E2 induced apoptosis through caspase $3 / 7, \mathrm{Bcl}-2, \mathrm{Bax}$, cyclooxygenase-2 (COX-2), and cleaved poly (ADP-ribose) polymerase pathways in GC cells. In addition, it increased autophagy by stimulating autophagy-related protein (ATG)5, ATG7, LC3-I/LC3-II, and inhibiting COX-2 activity in GC cells. We also found that $H$. zeylanica-E2 exhibited antiproliferation ability through cell cycle arrest in G0/G1 and $\mathrm{G} 2 / \mathrm{M}$ and suppressed the migration of GC cells. The anticancer effects of $H$. zeylanica-E2 in GC cells might be mediated partly through inhibition of tumor necrosis factor- $\alpha$ (TNF- $\alpha$ )-activated proinflammatory cytosolic phospholipase A2 (cPLA2)-COX-2-prostaglandin $E_{2}\left(\mathrm{PGE}_{2}\right)$ pathway.

Conclusions: Our results suggest that $H$. zeylanica-E2 has potential as a novel adjunctive agent for the treatment of GC.
\end{abstract}

Key words: Helminthostachys zeylanica; anti-inflammation; anticancer; gastric cancer

\section{Introduction}

Gastric cancer (GC) has a high incidence worldwide and its high mortality rate is related to malignant tumors [1]. According to the 2019 cancer statistics from the Department of Health in Taiwan, GC is the eighth leading cause of cancer-associated mortality in Taiwan (https://www.mohw.gov.tw/ cp-16-54482-1.html). GC is rarely detected at an early stage because it often causes no clinical symptoms and it is too advanced for curative surgical resection in more than $30 \%$ of patients with GC [2-4]. The 5-year 
survival outcome for patients with late-stage GC is poor after the initial diagnosis [5]. At present, gastrectomy remains the main therapy for GC [4, 6-8]. Therefore, the discovery of novel medicines to help the development of therapeutic strategies for GC management is necessary [9]. Chemotherapy is used for patients with advanced or recurrent GC and includes anti-vascular endothelial growth factor (anti-VEGF), anti-VEGF receptor, tyrosine kinase inhibitors, and Her2/Neu (also known as ErbB-2)mediated pathway blockers [10, 11]. Traditional herbal medicines are also used in combination with chemotherapy for the treatment of lung cancer, hepatocellular carcinoma (HCC), and GC [12-18].

The inflammatory response is one of the host defenses against tumors and can lead to tumor destruction with favorable prognosis. However, inflammation can also be related to poor clinical prognosis in patients with GC [19]. Chronic infection of the gastric mucosa with Helicobacter pylori is recognized as an important risk factor for GC [20]. Infection-induced chronic inflammation associated with inflammatory protein expression plays an important role in GC progression [21, 22]. Masami et al. found that $H$. pylori infection can promote the secretion of TNF- $\alpha$ and related inflammatory proteins, such as COX-2, $\mathrm{PGE}_{2}$, and cPLA2 through the nuclear factor $\kappa B(\mathrm{NF}-\kappa \mathrm{B})$ pathway [23-25]. Epstein-Barr virus is involved in almost $10 \%$ of all GC cases [26]. Chronic inflammation leads to oxidative stress in immune cells and gastric epithelial (GES-1) cells, which secrete inflammatory factors such as proinflammatory cytokines and chemokines. These inflammatory factors are the main contributor to DNA damage, apoptosis that can lead to gastric ulcers, and even GC. Failure of the host to eradicate infection with $H$. pylori or other viruses can cause chronic inflammation.

New Chinese herbal medicines with anti-inflammatory and antioxidative activities may be helpful in the prevention of chronic gastritis or as adjuvant chemotherapy for GC and may increase the survival rate of patients with GC [27-29]. Helminthostachys zeylanica is a herbaceous plant widely distributed in Southeast Asia that is rich in flavonoid compounds such as ugonins A-U [30-33]. Previous studies have found that neouginin A isolated from $H$. zeylanica can reduce the lipopolysaccharide (LPS)-induced expression of inflammation-related proteins through the NF- $\mathrm{BB}$ signaling pathway in macrophages [34]. Ugonin $M$ improves recovery from LPS-induced acute lung injury by regulating the NF- $\kappa \mathrm{B}$ and mitogen-activated protein kinase (MAPK) signaling pathways [35]. $H$. zeylanica has extensive pharmacological effects including anti-inflammatory, antioxidative, antiosteoporosis, hepatoprotective, immunomodulatory, and neuroprotective activities [30-32, 36]. Other researchers have reported that $H$. zeylanica extracts reduce inflammation and matrix metallopeptidase 9 (MMP-9) expression in bradykinin-activated brain astrocytes [36]. H. zeylanica extracts are also used to treat fever, inflammatory diseases, and bone loss caused by osteoarthritis in Taiwan [30, 31, 37, 38]. However, it is unknown whether the anticancer effects of $H$. zeylanica may be useful for the treatment of GC. We examined whether $H$. zeylanica extracts have anticancer effects in GC cells and, if so, we tried to identify the underlying mechanisms.

\section{Methods}

\section{The preparation of $\boldsymbol{H}$. zeylanica extracts}

The roots of $H$. zeylanica were purchased in Wanhua, Taiwan, and identified by Mr. Jun-Chih Ou. The roots of $H$. zeylanica were extracted initially with $50 \%$ ethanol. Then, the concentrated ethanol extract was separated by Sephadex LH-20 gel column chromatography eluting to get $H$. zeylanica-E1 $\left(\mathrm{H}_{2} \mathrm{O}\right.$ extract) and $H$. zeylanica-E2 (EtOAc extract). The detailed preparation of $H$. zeylanica-E1 and E2 as described in previous literature 36 and 39. The $H$. zeylanica-E1 and E2 in this article were prepared in keeping with a previously reported protocol $[36,39]$.

\section{Cell Lines and Cell Culture}

The human GC cell line, AGS, was obtained from the American Type Culture Collection (ATCC, CRL-1739). GES-1 and BGC823 cells were obtained from Dr. Q.X. Chen and Dr. D.W. Zhou, Xiamen University, Fujian, China. All cells were cultured in RPMI 1640 medium (Invitrogen, Carlsbad, CA, USA) containing $10 \%$ fetal bovine serum (FBS) plus 100 $\mathrm{IU} / \mathrm{mL}$ penicillin $\mathrm{G}, 100 \mathrm{mg} / \mathrm{mL}$ streptomycin sulfate (Sigma-Aldrich, St Louis, MO, USA), and nonessential amino acids at $37{ }^{\circ} \mathrm{C}$ in $95 \%$ air and $5 \% \mathrm{CO}_{2}$ as described previously [40]. The cells were either left untreated or were treated with H. zeylanica-E2 and/or TNF- $\alpha$.

\section{MTT Cell Survival Assay}

GES-1, AGS, and BGC823 cells (5000 cells) were seeded into 96-well plates with serum-free RPMI 1640 medium and cultured for $24 \mathrm{~h}$ at $37^{\circ} \mathrm{C}$. The cells were treated with $H$. zeylanica-E1 $(0,10,50,100,500,1,000$, 5000 , or $10000 \mu \mathrm{g} / \mathrm{mL})$ or H. zeylanica-E2 $(0,1,5,10$, 20, 40, 80, or $100 \mu \mathrm{g} / \mathrm{mL}$ ) [39] for 24 or $48 \mathrm{~h}$. Next, 0.25 $\mathrm{mg} / \mathrm{mL}$ MTT reagent (Bio-Rad Laboratories, Hercules, CA, USA) was added (100 $\mu \mathrm{L} /$ well $)$, the incubation was continued for $0.5 \mathrm{~h}$, and $100 \mu \mathrm{L}$ of 
dimethyl sulfoxide was then added to the medium. The optical density at $570 \mathrm{~nm}$ was detected using a microplate reader (SpectraMax i3; Kelowna International Scientific Inc., CA, USA) as described previously $[36,40]$.

\section{Quantitative Reverse Transcription Polymerase Chain Reaction}

GC cells were cultured in serum-free RPMI medium in $9 \mathrm{~cm}$ dishes for $24 \mathrm{~h}$ at $37^{\circ} \mathrm{C}$ and then treated with $H$. zeylanica-E2 or a selective COX-2 inhibitor (celecoxib, CLC) for 0,24 , or $48 \mathrm{~h}$. Total RNA was extracted using TRIzol® (Invitrogen), and the concentration of all RNA samples was detected using a Nano-100 Micro-Spectrophotometer (CLUBIO, Taipei, Taiwan) [41]. Next, cDNA was synthesized using an iScript ${ }^{\mathrm{TM}}$ cDNA Synthesis Kit (Bio-Rad Laboratories) and amplified on a spectrofluorometric thermal cycler (iCycler; Bio-Rad Laboratories). To assess COX-2 mRNA expression in GC cells, qRT-PCR was performed as described previously, using $A C T B$ as the internal control $[42,43]$. Fluorescence emitted by SoFast EvaGreen Supermix was assayed using the CFX Connect Real-Time System (both from Bio-Rad). The primers used for RT-qPCR were as follows: human PTGS2 (forward, 5'-CTGCGCCTTTTCAAGG ATGG-3', and reverse, 5'-CCCCACAGCAAACCGT AGAT-3') and human ACTB (forward, 5'-AAAGACC TGTACGCCAACAC-3', and reverse, 5'-GTCATACT CCTGCTTGCTGAT-3'). Relative gene expression was determined by the $\Delta \Delta \mathrm{Ct}$ method, where $\mathrm{Ct}$ represents the mean threshold cycle.

\section{Western Blot}

Western blotting was conducted as described previously [43]. Total proteins were extracted from GC cells grown in serum-free RPMI medium and seeded in $9 \mathrm{~cm}$ dishes and cultured for $24 \mathrm{~h}$ at $37^{\circ} \mathrm{C}$. The cells were then treated with $H$. zeylanica-E2 or CLC plus TNF- $\alpha$ or the arachidonic acid (AA) derivative AACOCF3, which is a CPLA2 inhibitor for 0,24 , or $48 \mathrm{~h}$. Next, the cells were harvested and the proteins were separated by sodium dodecyl sulfate-polyacrylamide gel electrophoresis and then transferred to polyvinylidene fluoride membranes. Western blotting was completed using standard procedures, as described previously [44]. Rabbit anti-Bcl-2, anti-Bax, anti-cleaved PARP, anti-COX-2, anti-autophagy-related protein (ATG)5, anti-ATG7, anti-Beclin-1, and anti-LC3-I/LC3-II were purchased from Cell Signaling Technology (Danvers, MA, USA) and used at dilution of 1:1000. Mouse anti-GAPDH antibody was obtained from Santa Cruz Biotechnology (Santa Cruz, CA, USA). Finally, the protein bands were detected using an ECL-detecting reagent (Visual Protein Biotech, New Taipei City, Taiwan) and captured using a UVP BioSpectrum 500 Imaging System (UVP, Upland, CA, USA). Image densitometry analysis was quantified using Image Lab $^{\text {TM }}$ Software (Bio-Rad Laboratories).

\section{ELISA}

After culture for $24 \mathrm{~h}$, GC cells were incubated with serum-free RPMI 1640 medium. $\mathrm{PGE}_{2}$ protein level in the medium from cells treated with $H$. zeylanica-E2 or CLC for 0,24 , or $48 \mathrm{~h}$ was measured using a human protein $\mathrm{PGE}_{2}$ enzyme immunoassay kit (Enzo Life Sciences, Farmingdale, NY, USA). Fluorescence intensity was measured at $450 \mathrm{~nm}$ using a SpectraMax i3 microplate reader (Kelowna International Scientific Inc.) [40, 45].

\section{Flow Cytometry Analysis of Apoptosis Using Annexin V-Propidium lodine Staining and Caspase 3/7 Staining Assays}

GC cells were seeded in $9 \mathrm{~cm}$ dishes and grown in serum-free RPMI 1640 medium for $24 \mathrm{~h}$ at $37^{\circ} \mathrm{C}$ and then treated with 10 or $5 \mu \mathrm{g} / \mathrm{mL} \mathrm{H}$. zeylanica-E2 for 0,24 , or $48 \mathrm{~h}$. Cell apoptosis was assessed using flow cytometry. Cells were harvested using standard procedures as described previously [46] and prepared using a Muse ${ }^{\circledR}$ Annexin V \& Dead Cell Kit and Muse ${ }^{\circledR}$ Caspase-3/7 Assay Kit. Data were collected and analyzed using a Muse ${ }^{\circledR}$ Cell Analyzer flow cytometer (all kits and equipment from Merck).

\section{Cell Cycle Assay}

GC cells were treated as described above for the cell cultures used for cell cycle analysis by flow cytometry and harvested using standard procedures as described previously [47]. The cells were prepared using a Muse ${ }^{\circledR}$ Cell cycle Kit, and the data were collected and analyzed using a Muse ${ }^{\circledR}$ Cell Analyzer flow cytometer (all from Merck).

\section{Colony-Forming and Cell Proliferation Assays}

In the colony-forming assay, $1 \times 10^{3} \mathrm{GC}$ cells were seeded in serum-free RPMI 1640 medium in six-well plates and grown for $24 \mathrm{~h}$. GC cells were treated with 0,10 , or $5 \mu \mathrm{g} / \mathrm{mL} \mathrm{H}$. zeylanica-E2. After incubation for 2 weeks, colonies were fixed and stained with crystal violet. Colony numbers were photographed and measured using Image Lab ${ }^{\mathrm{TM}}$ Software (Bio-Rad) [47]. For the analysis of cell proliferation, $1 \times 10^{3} \mathrm{GC}$ cells were plated in wells of a six-well plate and treated as described for cell culture. Viable cells were trypsinized and counted on days 1, 7, 9, and 11 or 13 .

\section{Scratch Wound-Healing Assay}

The in vitro scratch wound-healing assay was used to assess the effects of $H$. zeylanica-E2 on the 
metastatic activity of GC cells. GC cells $\left(3 \times 10^{5}\right)$ in serum-free RPMI 1640 medium were seeded in a six-well plate and incubated for $24 \mathrm{~h}$. GC cells were treated with 10 or $5 \mu \mathrm{g} / \mathrm{mL} \mathrm{H}$. zeylanica-E2 and $10 \mu \mathrm{M}$ hydroxyurea for 0,24 , or $48 \mathrm{~h}$. When the cells had reached $100 \%$ confluence, two parallel wounds of 1 $\mathrm{mm}$ were made using a pipette tip. The number of cells that moved into the wound was measured after $48 \mathrm{~h}$ and photographed using a Leica Microsystems microscope (Wetzlar, Mannheim, Germany) as described previously [48].

\section{Statistical Analysis}

Quantitative data were analyzed using Student's-t-test (for two groups) or one-way ANOVA (for more than two groups). Values are expressed as mean \pm SEM. A $p$ value $<0.05$ was considered significant [49]. All experiments were performed at least three times independently. The data from Western blotting were analyzed using image $\mathrm{Lab}^{\mathrm{TM}}$ 5.0 software (Bio-Rad Laboratories). All results were analyzed using GraphPad Prism software (GraphPad, San Diego, CA, USA).

(A)

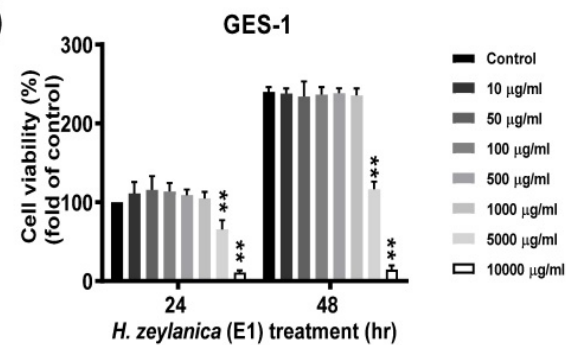

(B)

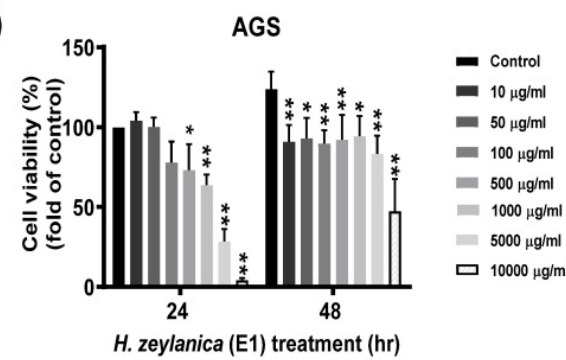

(C)

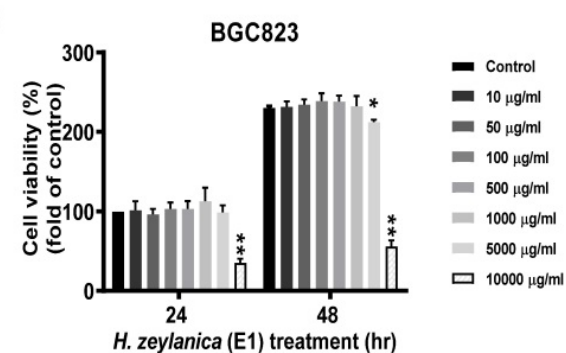

\section{Results}

Effects of H. zeylanica Extracts (E1 and E2) on the Viability of GC and Normal Cells

The compounds in H. zeylanica extracts (E1 and E2) were analyzed using high-performance liquid chromatography (HPLC). The H. zeylanica secondary extracts with $H$. zeylanica-E1 and $H$. zeylanica-E2 were prepared. We found that both $H$. zeylanica extracts contained mostly flavonoids compounds (the major compounds are ugonins J and K) [39].

Next, to evaluate whether the $H$. zeylanica extracts E1 and E2 exhibited anticancer effects in vitro, serial dilutions of these extracts were prepared in RPMI medium and incubated with GC and normal GES-1 cells for 24 or 48 h. 3-[4,5-dimethylthiazol2-yl]-2,5 diphenyl tetrazolium bromide (MTT) assay was used to assess the effects of the two extracts on cell viability in two GC cell lines (AGS and BGC823) and the normal GES-1 cell line. $H$. zeylanica-E1 treatment up to the concentration of $1000 \mu \mathrm{g} / \mathrm{mL}$ for 24 or $48 \mathrm{~h}$ did not affect the viability of GES-1 cells (Figure 1A, left). By contrast, these concentrations
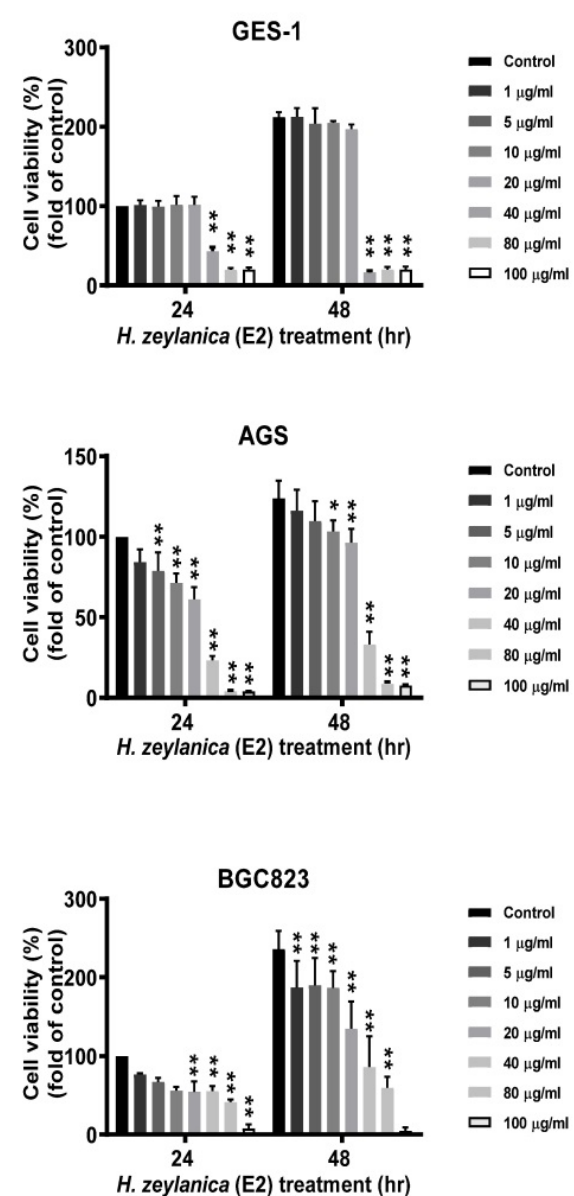

Figure 1. Effects of $\boldsymbol{H}$. zeylanica extracts (E1 and E2) on the viability of GC and normal GES-1 cells. (A) normal GES-1 cell line, (B) AGS, and (C) BGC823 cells were treated with $\mathrm{H}$. zeylanica-El and $\mathrm{H}$. zeylanica-E2 at the concentrations indicated for 24 or $48 \mathrm{~h}$. Viability of cells exposed to various concentrations of $H$. zeylanica extracts (E1 and E2) was assessed using the MTT assay and were expressed relative to that of untreated cells incubated for $24 \mathrm{~h}$. Data are presented as mean \pm standard error of the mean (SEM) for three independent experiments. Student's-t-test or one-way analysis of variance (ANOVA) was used for comparison with the control values. $(* * p<0.01, * p<0.05)$. 
significantly altered the viability of AGS cells incubated for $24 \mathrm{~h}$ and $48 \mathrm{~h}$ (Figure 1B, left). Treatment with E1 did not alter the viability of BGC823 cells at most concentrations and for both incubation times, except at a concentration of 10000 $\mu \mathrm{g} / \mathrm{mL}$ (Figure 1C, left). These results indicated that H. zeylanica-E1 up to the concentration of $1000 \mu \mathrm{g} / \mathrm{mL}$ was therefore not suitable for studying different types of GC cells. This extract was not used in the follow-up experiments. $H$. zeylanica-E2 up to the dose of 20 $\mu \mathrm{g} / \mathrm{mL}$ for $24 \mathrm{~h}$ and $48 \mathrm{~h}$ did not reduce the viability of GES-1 cells (Figure 1A, right) but had a significant effect on the viability of AGS cells (Figure 1B, right) and BGC823 cells (Figure 1C, right) in the concentration-dependent manner. These cell viability profiles showed that $H$. zeylanica-E2 induced dose- and time-dependent effects on the death of GC cells. Our results suggest that $H$. zeylanica-E2 is selectively toxic to GC cells, but has minimal or no toxicity for normal GES-1 cells (Figure 1). Therefore, we chose to use $H$. zeylanica-E2 at concentrations of $10 \mu \mathrm{g} / \mathrm{mL}$ in AGS cells and $5 \mu \mathrm{g} / \mathrm{mL}$ in BGC823 cells for further evaluation of the anticancer effects.

\section{Effects of H. zeylanica-E2 on GC Cell Apoptosis}

We next explored whether the molecular mechanism responsible for the $H$. zeylanica-E2 inhibition of the growth of GC cells involves apoptosis. Cells were stained with Annexin V-7amino actinomycin (7-AAD) and analyzed by flow cytometry (Figure 2A). AGS cells treated with $H$.

(A)
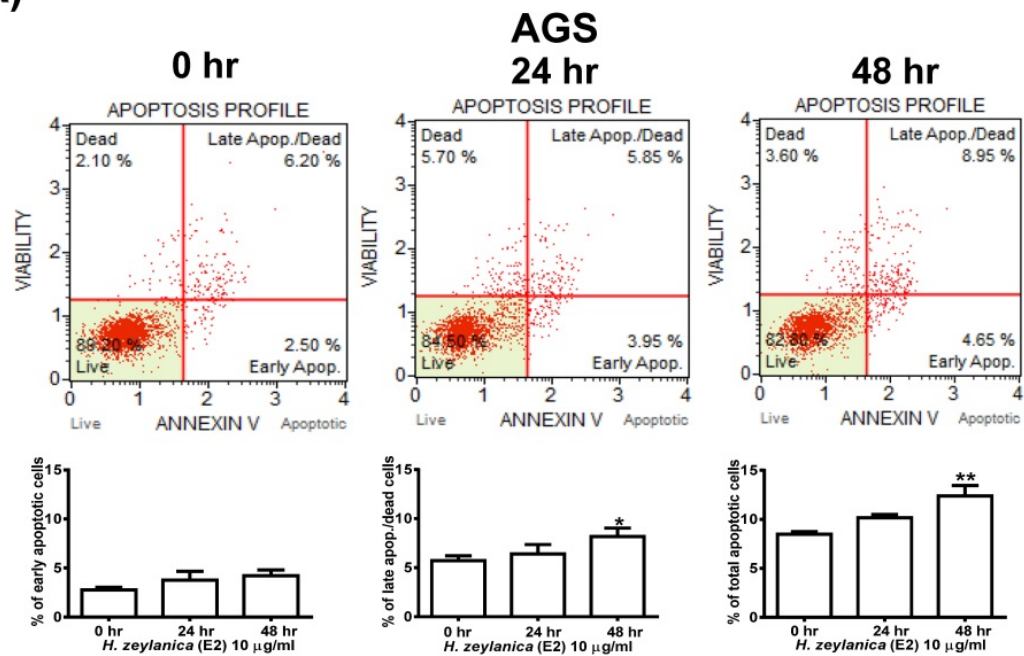

(B)
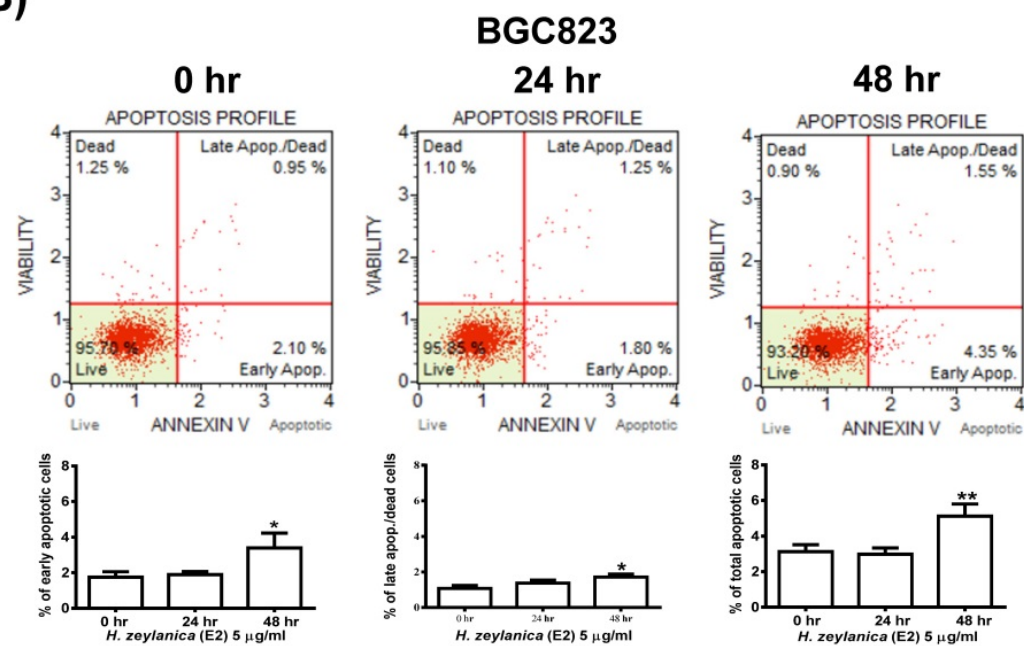

Figure 2. Effects of $\boldsymbol{H}$. zeylanica-E2 on GC cell apoptosis. (A) AGS cells were treated with $H$. zeylanica-E2 $(10 \mu \mathrm{g} / \mathrm{mL})$, and $(\mathbf{B}) \mathrm{BGC} 823 \mathrm{cells}$ were treated with $H$. zeylanica-E2 $(5 \mu \mathrm{g} / \mathrm{mL})$ for 0,24 , or $48 \mathrm{~h}$. The cells from different experimental groups were collected and incubated with Muse ${ }^{\mathrm{TM}}$ Annexin $\vee \&$ Dead Cell reagent (Merck Millipore, Billerica, MA, USA) for 20 min at room temperature and then analyzed using a Muse TM Cell Analyzer (Merck). Four populations of cells (live, early apoptotic, late apoptotic, and dead) were quantified. The upper left shows mostly nuclear debris: Annexin $\mathrm{V}^{-}$and 7-AAD+; lower left shows nonapoptotic cells: Annexin $\mathrm{V}^{-}$and 7-AAD-; lower right shows early apoptotic cells: Annexin $\mathrm{V}^{+}$and 7-AAD-; and the upper right shows late-stage apoptotic and dead cells: $A$ nnexin $\mathrm{V}^{+}$and 7-AAD+ the quantitative results. Data are presented as mean \pm SEM of at least three independent experiments. Student's-t-test or one-way ANOVA was used for comparison with the control values. $\left(* * p<0.01, *_{p}<0.05\right)$. 
zeylanica-E2 exhibited apoptosis in a time-dependent manner, especially in late-stage apoptosis. $H$. zeylanica-E2 treatment significantly increased the total cell apoptotic rate from $8.7 \%(0 \mathrm{~h})$ to $13.6 \%(48 \mathrm{~h})(p<$ $0.05)$ and the late cell apoptotic rate from $6.2 \%(0 \mathrm{~h})$ to $8.95 \%(48$ h) $(p<0.01)$. In BGC823 cells, H. zeylanica-E2 treatment significantly increased the total cell apoptotic rate from $3.05 \%(0 \mathrm{~h})$ to $5.9 \%(48 \mathrm{~h})(p<0.05)$ and the early cell apoptotic rate from $2.1 \%(0 \mathrm{~h})$ to $4.35 \%(48$ h) $(p<0.01)$ (Figure 2B). Notably, BGC823 cells treated with $H$. zeylanica-E2 exhibited apoptosis in a time-dependent manner, especially in early-stage apoptosis, which accounted for a higher proportion of early-stage apoptosis in cells incubated for $48 \mathrm{~h}$ compared with $24 \mathrm{~h}$.

\section{Effects of H. zeylanica-E2 on GC Cell Apoptosis by Activation of Caspase 3/7, Bcl-2, Bax, and Cleaved Poly (ADP-Ribose) Polymerase}

To explore further whether the activity of caspase 3/7 is involved in apoptosis, the cells were stained for caspases 3/7 and 7-AAD and then analyzed by flow cytometry. As shown in Figure 3A, GC cells treated with $H$. zeylanica-E2 for 0,24 , or $48 \mathrm{~h}$ exhibited apoptosis in a time-dependent manner.

(A)

$\mathrm{O} \mathrm{hr}$
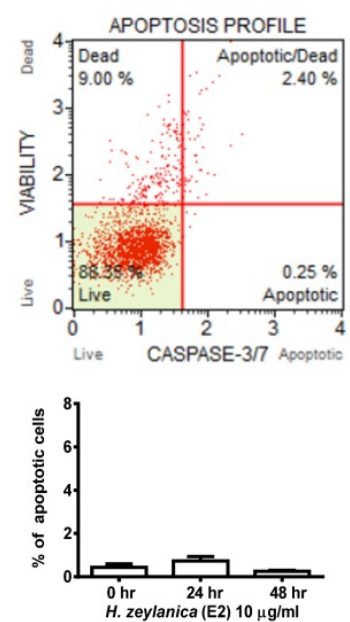

(B)
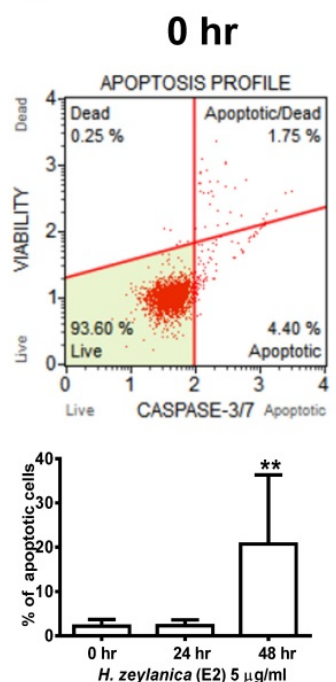

AGS

$24 \mathrm{hr}$
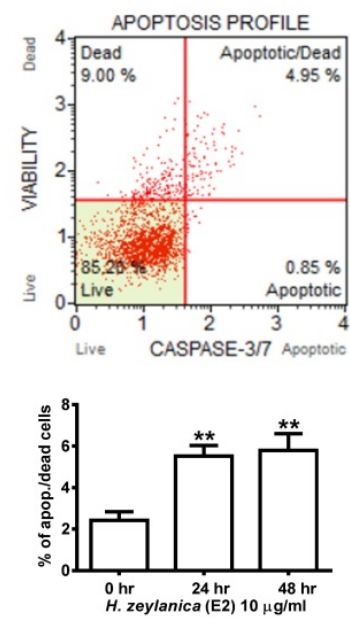
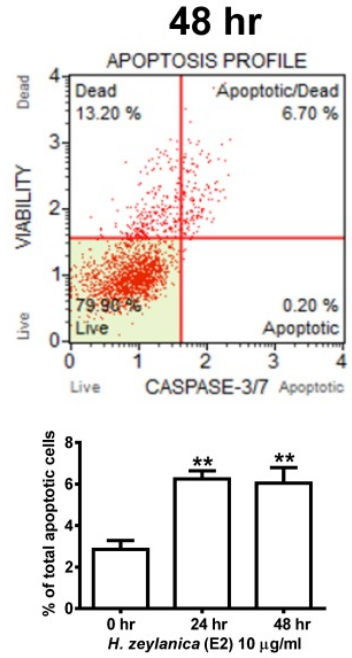

BGC823

$24 \mathrm{hr}$
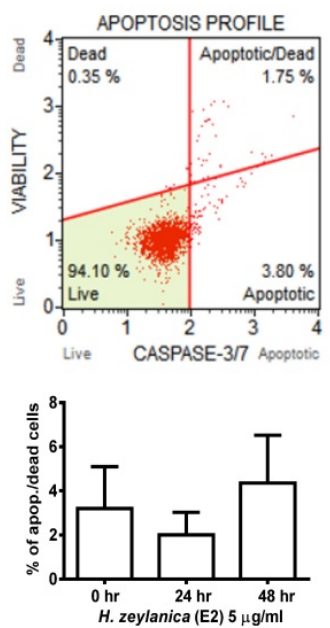

$48 \mathrm{hr}$
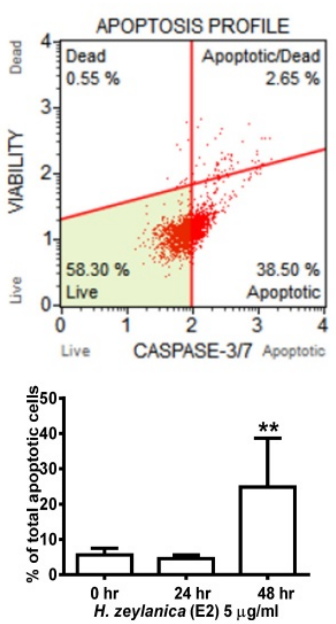

Figure 3. Effects of $\boldsymbol{H}$. zeylanica-E2 on apoptosis of $\mathbf{G C}$ cells through changes in caspase $3 / 7$ activity. (A) AGS cells were treated with $H$. zeylanica-E2 (10 $\mu$ g/mL), and (B) BGC823 cells were treated with $\mathrm{H}$. zeylanica-E2 $(5 \mu \mathrm{g} / \mathrm{mL})$ for 0,24 , or $48 \mathrm{~h}$. The cells from different experimental groups were collected and incubated with Muse ${ }^{\mathrm{TM}}$ Caspase-3/7 working solution (Merck) for $30 \mathrm{~min}$ at $37^{\circ} \mathrm{C}$ and then mixed thoroughly with 7-AAD while protected from light at room temperature for 5 min and analyzed using a Muse ${ }^{\mathrm{TM}}$ Cell Analyzer (Merck). Four populations of cells (live, necrotic, apoptotic, and late apoptotic/dead) were quantified. The lower left shows live cells: caspase-3/7- and 7-AAD-; lower right shows apoptotic cells exhibiting caspase-3/7 activity: caspase-3/7+ and 7-AAD-; upper left shows necrotic cells: caspase-3/7- and 7-AAD+; and upper right shows late apoptotic/dead cells: caspase- $3 / 7^{+}$and $7-A A D^{+}$. Data are presented as mean \pm SEM of at least three independent experiments. Student's-t-test or one-way ANOVA was used for comparison with the control. $(* * p<0.01, * p<0.05)$. 
AGS cells exhibited a higher proportion of late-stage apoptosis, and BGC823 cells had a higher proportion of early-stage apoptosis. In AGS cells, $H$. zeylanica-E2 treatment significantly increased the total cell apoptotic rate from $2.65 \%$ at $0 \mathrm{~h}$ to $6.9 \%$ at $48 \mathrm{~h}$ (p < 0.01 ) and the late cell apoptotic rate from $2.4 \%$ at $0 \mathrm{~h}$ to $6.7 \%$ at $48 \mathrm{~h}(\mathrm{p}<0.01)$. In BGC823 cells, H. zeylanica-E2 treatment significantly increased the total cell apoptotic rate from $6.15 \%$ at $0 \mathrm{~h}$ to $41.15 \%$ at $48 \mathrm{~h}(\mathrm{p}<$ 0.01 ) and the early cell apoptotic rate from $4.4 \%$ at $0 \mathrm{~h}$ to $38.5 \%$ at $48 \mathrm{~h}(\mathrm{p}<0.01)$ (Figure $3 \mathrm{~B})$.

Proteins related to apoptosis were observed using Western blotting. Treatment with $H$. zeylanica-E2 for 24 or $48 \mathrm{~h}$ significantly increased cleaved poly (ADP-ribose) polymerase (PARP) content in AGS cells (by 1.78-fold at $48 \mathrm{~h} ; p<0.01$ ) and BGC823 cells (by 1.65-fold at $48 \mathrm{~h} ; p<0.05$ ) compared with the control $(0 \mathrm{~h})$. (Figure $4 \mathrm{~A}$ and $4 \mathrm{~B}$, left). Treatment with $H$. zeylanica-E2 for 24 or $48 \mathrm{~h}$ significantly decreased Bcl-2 content in AGS cells (0.29 of the control value at $48 \mathrm{~h} ; p<0.01$ ) and increased Bax content in BGC823 cells (by 1.75-fold at $48 \mathrm{~h} ; p<0.05$ ) compared with the control $(0 \mathrm{~h})$ (Figure $4 \mathrm{~A}$ and $4 \mathrm{~B}$, right). These data suggest that activated caspase $3 / 7$, Bcl-2, Bax, and cleaved PARP may be involved in the effects of $H$. zeylanica-E2 on the endogenous proapoptotic pathway in GC cells.
Effects of $H$. zeylanica-E2 on Apoptosis and Autophagy in GC Cells through changes in the Proinflammatory COX-2 Protein

Previous studies found that COX-2 overexpression correlates with GC development [50-53]. Additionally, H. pylori induces cell chronic inflammation, which leads to the aberrant in vitro expression of heat-shock protein 70 and apoptosis-related proteins (Bax and Bcl-2), and promotion of COX-2 expression in GC cells [54, 55]. Next, we explored whether the inhibitory effects of $H$. zeylanica-E2 on proapoptotic proteins are associated with the proinflammatory COX-2 protein in GC cells. As shown in Figure 5A, compared with the control, treatment of AGS cells with $H$. zeylanica-E2 or CLC significantly reduced the levels of Bcl-2 (0.51 and 0.72 of the control value, respectively; $p<0.01$ for both) and COX-2 (0.45 and 0.34 of the control value; $p<0.01$ for both). Treatment of AGS cells with H. zeylanica-E2 or CLC increased the cleaved PARP level (by 1.22and 3.11-fold, respectively; $p<0.01$ for both). A similar pattern was also observed in BGC823 cells. In BGC823 cells, treatment of $H$. zeylanica-E2 or CLC significantly increased the levels of Bax (1.75- and 1.65-fold, respectively; $p<0.01$ for both) and cleaved PARP (1.48- and 1.35-fold, respectively; $p<0.05$ for both), but decreased the COX-2 level (to 0.27 and 0.28 of the control value, respectively; $p<0.01$ for both). These data suggest that proinflammatory COX-2 protein is involved in GC cell apoptosis induced by the E2 extract.
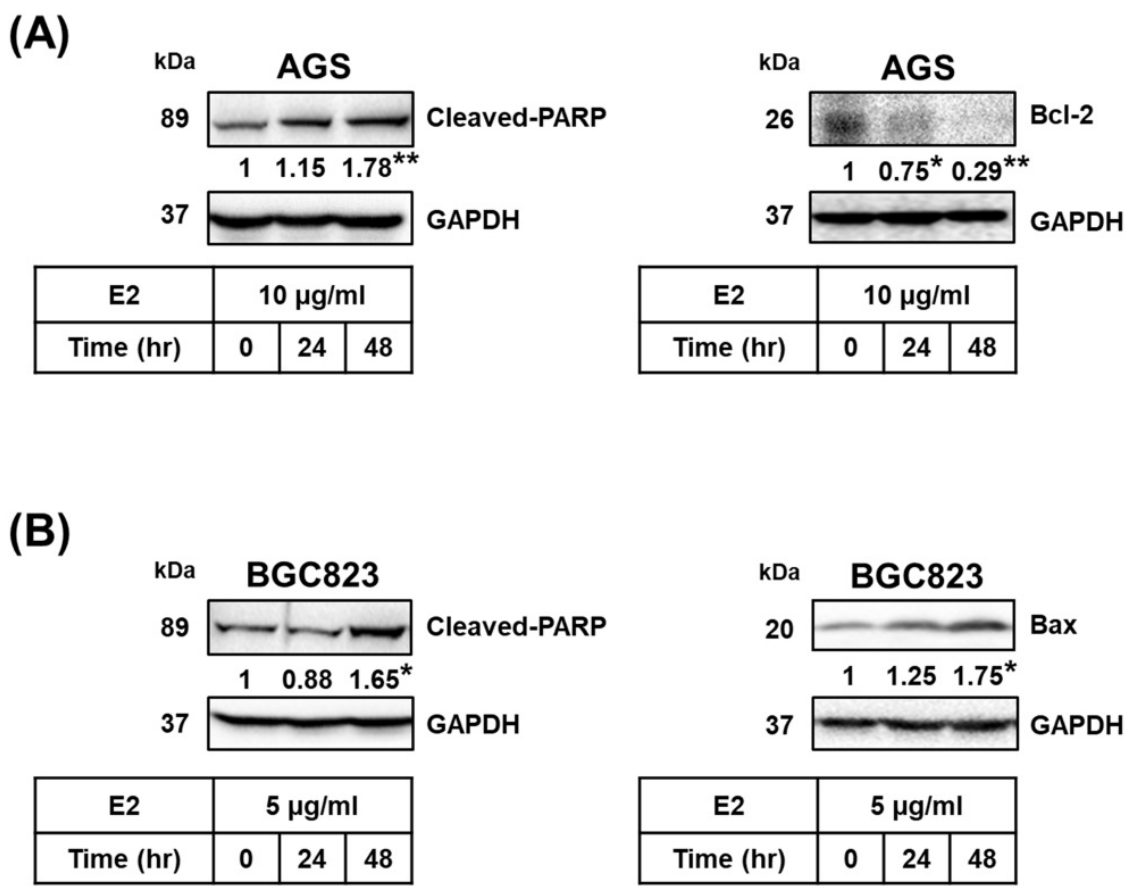

Figure 4. Effects of $\boldsymbol{H}$. zeylanica-E2 on apoptosis of GC cells through changes in Bcl-2, Bax, and cleaved PARP. (A) AGS and (B) BGC823 cells were treated without or with $\mathrm{H}$. zeylanica-E2 for 0,24 , or $48 \mathrm{~h}$. The contents of proteins related to apoptosis (cleaved PARP, Bcl-2, and Bax) were quantified by Western blotting. GAPDH was used as the internal control, and the expression ratio of these proteins was quantified. Data are presented as mean \pm SEM of three independent experiments. Student's-t-test or one-way ANOVA was used for comparison with the control. $(* p<0.05, * * p<0.01)$. 
(A)
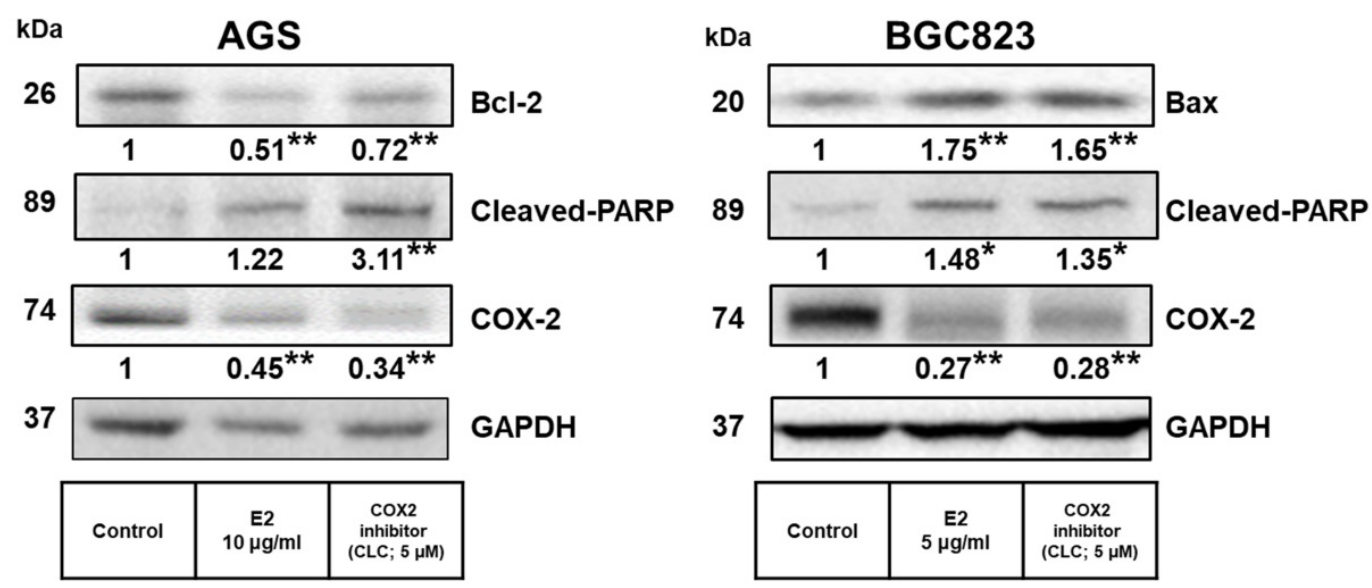

(B)
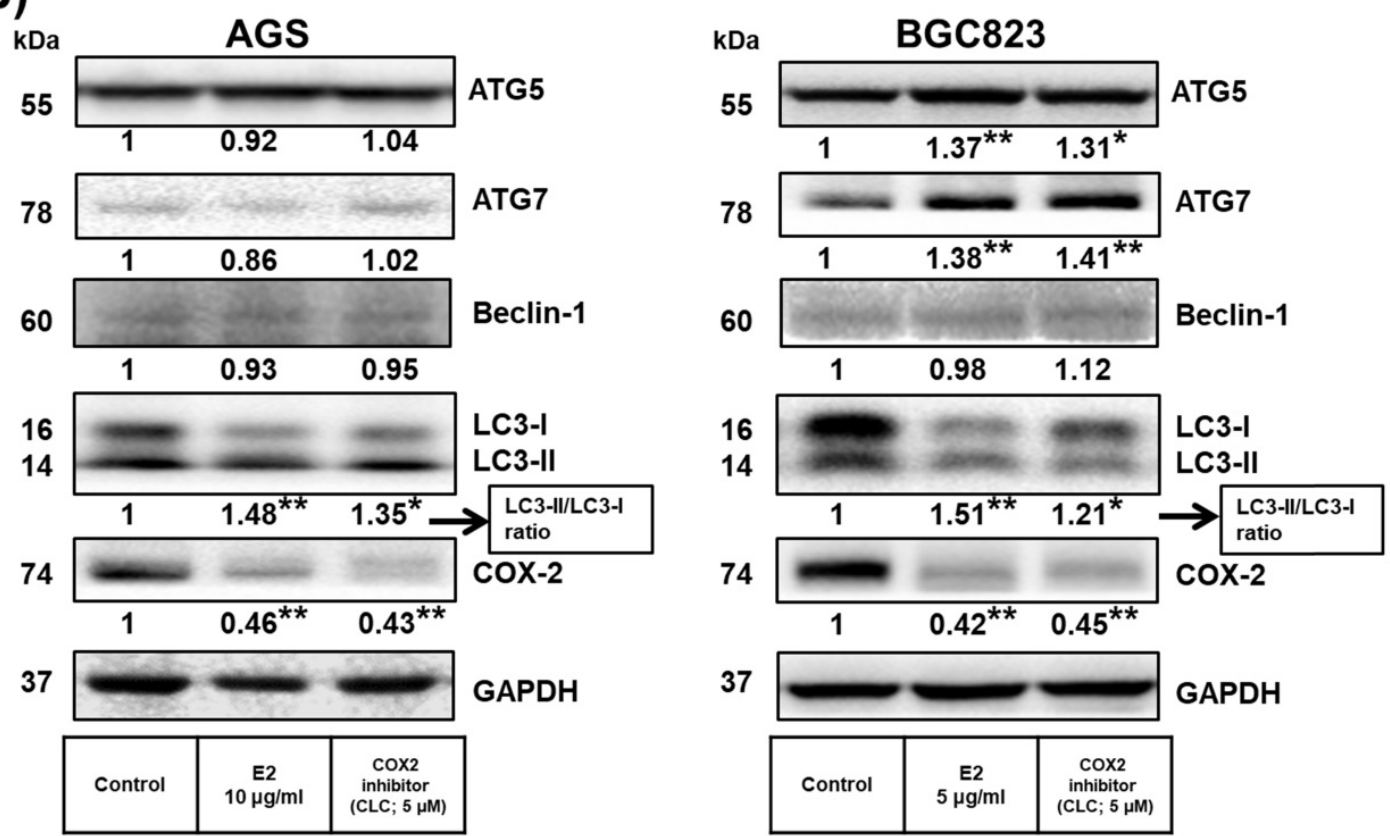

Figure 5. Effects of $\boldsymbol{H}$. zeylanica-E2 on GC cell apoptosis and autophagy via COX-2 protein. (A) AGS and (B) BGC823 cells were treated without or with $H$. zeylanica-E2 and $5 \mu \mathrm{M} \mathrm{CLC}$. The contents of proteins associated with apoptosis (cleaved PARP, Bcl-2, Bax, ATG5, ATG7, Beclin-1, LC3-I, LC3-II, and COX-2) were determined by Western blotting. GAPDH was used as an internal control. Autophagy is represented by LC3 conversion, expressed as the LC3-II/LC3-I ratio. Data are presented as mean \pm SEM of three independent experiments. Student's-t-test or one-way ANOVA was used for comparison with the control. $\left({ }^{*} p<0.05\right.$, $\left.* * p<0.01\right)$.

Next, we examined whether H. zeylanica-E2 can protect cells against oxidative damage by modulating autophagy. The levels of ATGs in GC cells were measured using Western blotting. As shown in Figure 5B, H. zeylanica-E2 and CLC significantly decreased the accumulation of COX-2 proteins. By contrast, the ratios of the two forms of the microtubule-associated protein 1A/1B light chain 3 (LC3), LC3-II/LC3-I were significantly increased in AGS and BGC823 cells. Notably, in BGC823 cells, the expression of ATG5 was increased significantly (by 1.37- and 1.31-fold for E2 and CLC; $p<0.01, p<0.05$, respectively) and that of ATG7 was increased significantly (by 1.38- and 1.41-fold, respectively; $p<0.01$ for both). Taken together, these findings suggest that apoptosis of GC cells caused by $H$. zeylanica-E2 involves effects on autophagy that are partly related to COX-2 activation.

\section{Effects of $H$. zeylanica-E2 on $\mathrm{PGE}_{2}$ production through downregulation of the Expression of Proinflammatory COX-2 in GC Cells}

Next, to determine whether the in vitro antitumor effects of $H$. zeylanica are mediated through proinflammatory COX-2, we investigate the molecular mechanism underlying the effects of the extract. Treatment with $H$. zeylanica-E2 significantly reduced the expression of COX-2 mRNA and protein levels in AGS cells (0.17- and 0.35-fold at $48 \mathrm{~h}$, respectively; $p<0.01$ for both) and in BGC823 cells (0.38- and 0.29-fold at $48 \mathrm{~h} ; p<0.05$ and $p<0.01$, 
respectively) in a time-dependent manner (Figure 6A and $6 \mathrm{~B})$. It was found in GC cells that the longer the treatment time of $H$. zeylanica-E2, the less the expression of $\mathrm{PGE}_{2}$. Among them, only treatment with $\mathrm{H}$. zeylanica-E2 for $48 \mathrm{~h}$ significantly reduced the $\mathrm{PGE}_{2}$ protein level in BGC823 cells compared with control cells $(0 \mathrm{~h})$ (Figure 6C). As shown in Figure 6D, $\mathrm{PGE}_{2}$ protein level did not change significantly in AGS cells treated with $H$. zeylanica-E2 or CLC (0.89

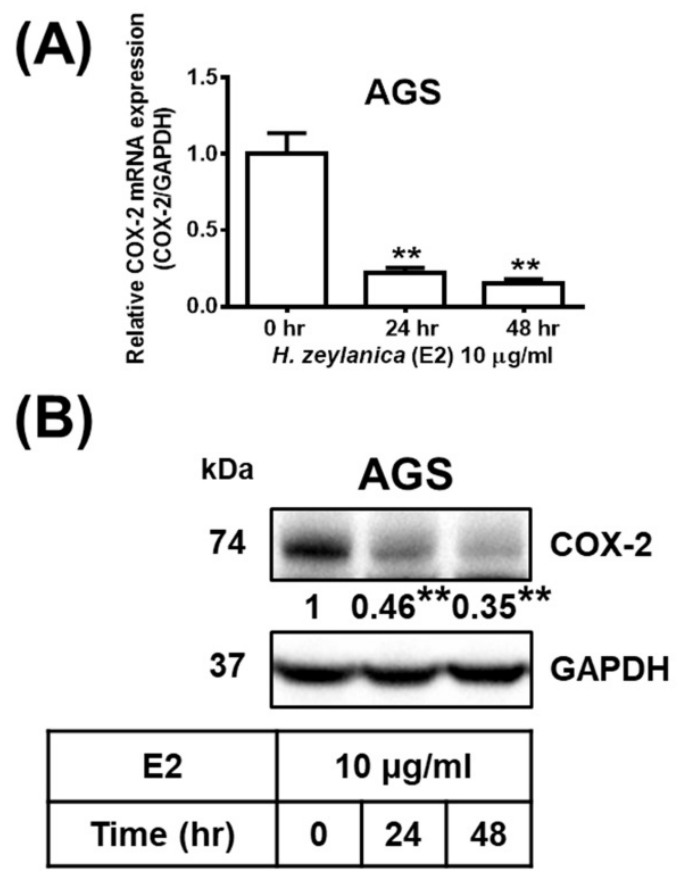

(C)

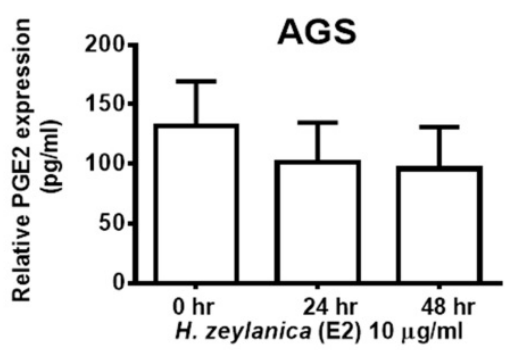

(D)

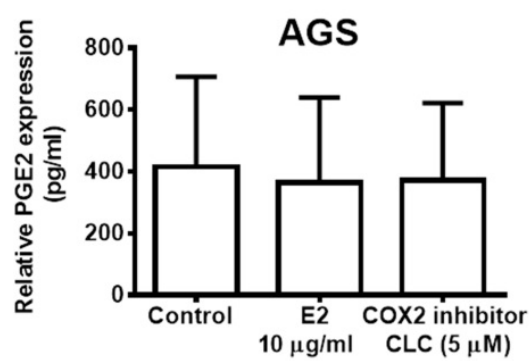

and 0.91 of the control values, respectively) compared with untreated control cells. In BGC823 cells, $H$. zeylanica-E2 and CLC treatment reduced $\mathrm{PGE}_{2}$ protein level ( 0.72 and 0.65 of the control values, respectively), but only the change induced by CLC was significant $(p<0.01)$ compared with untreated control cells. These data suggest that the $H$. zeylanica-E2-induced decrease in $\mathrm{PGE}_{2}$ production was mediated through proinflammatory COX-2 in GC cells.
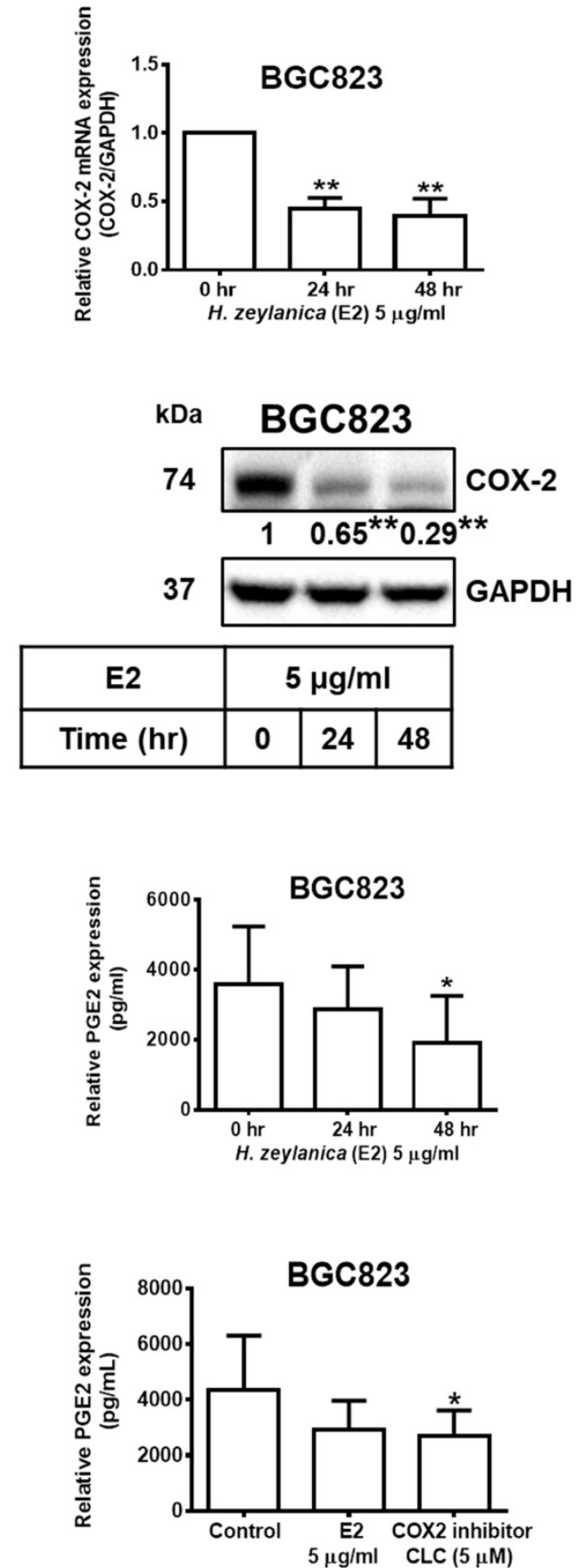

Figure 6. Effects of $\boldsymbol{H}$. zeylanica-E2 on PGE 2 expression mediated through COX-2 expression. AGS cells were treated with $10 \mu g / m L ~ H . ~ z e y l a n i c a-E 2$, and BGC823 cells were treated with $5 \mu \mathrm{g} / \mathrm{mL}$ H. zeylanica-E2 for 0,24 , or $48 \mathrm{~h}$. The COX-2 mRNA transcript and protein expression levels were determined using (A) quantitative reverse transcription polymerase chain reaction (qRT-PCR) and (B) Western blotting. GAPDH was used as an internal control. (C) The PEG 2 protein level was measured using an enzyme-linked immunosorbent assay (ELISA). (D) AGS and BGC823 cells were treated without or with $\mathrm{H}$. zeylanica-E2 or $5 \mu \mathrm{M}$ CLC for $24 \mathrm{~h}$. The conditioned medium was collected and the PEG 2 level was measured by ELISA. Data are presented as mean \pm SEM of three independent experiments. Student's-t-test or one-way ANOVA was used for comparison with the control. $(* p<0.05, * * p<0.01)$. 


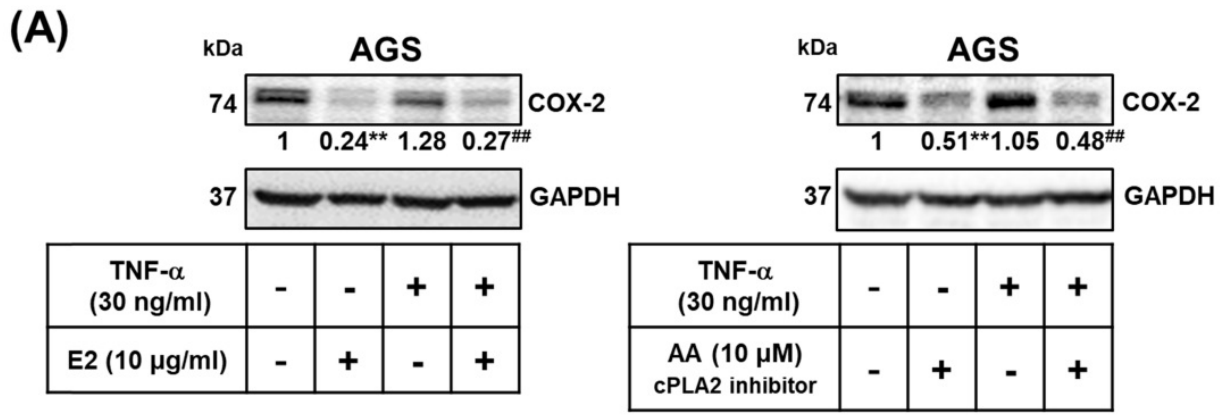

(B)

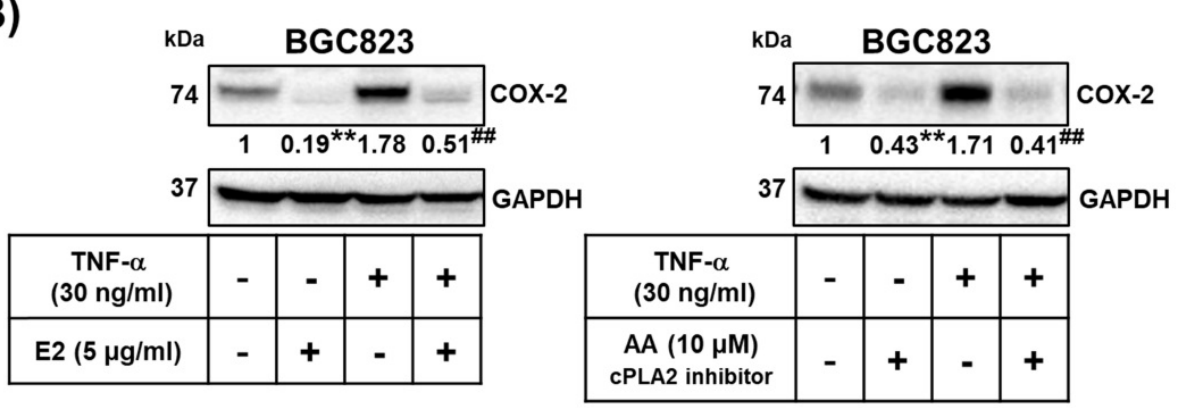

Figure 7. Role of cPLA2 in the effects of $\boldsymbol{H}$. zeylanica-E2 on TNF- $\alpha$-induced COX-2 expression. (A) AGS cells were pretreated with or without $H$. zeylanica-E2 (left) or AA (right) and then incubated with TNF- $\alpha$ for 24 h. (B) BGC823 cells were pretreated with $H$. zeylanica-E2 (left) or AA (right) and then stimulated with TNF- $\alpha$ for 24 h. The COX-2 protein level was determined by Western blotting. GAPDH was used as a loading control. The expression level of COX-2 was quantified according to the position of the electrophoresis band. The results are expressed as the quantified value for COX-2 divided by that of GAPDH. Data are presented as mean \pm SEM of three independent experiments. Student's-t-test or one-way ANOVA was used for comparison with the control. $\left(\# p<0.05\right.$, \#p $p 0.01$ compared with the TNF- $\alpha$-stimulated group; ${ }^{*} p<0.05$, $* * p$ $<0.01$ compared with the control).

\section{Effects of $H$. zeylanica-E2 on TNF- $\alpha$ Induced COX-2 Expression by modulating CPLA2}

We examined whether the effects of $H$. zeylanica-E2 involve the proinflammatory COX-2mediated pathway. TNF- $\alpha$ is produced by tumor and immune cells, activates the COX-2-PGE 2 pathway, and plays an important role in the maintenance of tumor cells $[51,53,56,57]$. We examined whether $H$. zeylanica-E2 can also inhibit COX-2 expression in AGS and BGC823 cells treated with TNF- $\alpha$. H. zeylanica-E2 significantly reduced the expression of COX-2 protein in AGS cells $(0.24$ of the control value; $p<0.01)$ and in BGC823 cells (0.19 of the control value; $p<0.01$ ) compared with control cells. H. zeylanica-E2 also significantly reduced the expression of COX-2 protein in TNF- $\alpha$-stimulated AGS cells $(0.27$ of the control value; $p<0.01)$ and in BGC823 cells $(0.51$ of the control value; $p<0.01)$ compared with control cells stimulated with TNF- $\alpha$ (Figure 7A, left and Figure 7B, left).

Next, to evaluate whether cPLA2 mediates COX-2 expression, AGS and BGC823 cells were pretreated with or without $\mathrm{AA}$, and then incubated with or without TNF- $\alpha$. AA significantly reduced the expression of COX-2 protein in AGS cells ( 0.51 of the control value; $p<0.01)$ and in BGC823 cells ( 0.43 of the control value; $p<0.01)$ compared with control cells. AA also significantly reduced TNF- $\alpha$-stimulated COX-2 expression in AGS cells (0.48 of the control value; $p<0.01)$ and in BGC823 cells (0.41 of the control value; $p<0.01)$ compared with control cells stimulated with TNF- $\alpha$ (Figure 7A, right and Figure $7 \mathrm{~B}$ right). These findings suggest that $H$. zeylanica-E2 reduced the TNF- $\alpha$-induced expression of proinflammatory COX-2 expression via cPLA2.

\section{Effects of $H$. zeylanica-E2 on GC Cell Proliferation and Colony Formation through Cell Cycle Arrest in G0/G1 and G2/M Phases}

To examine the effects of $H$. zeylanica-E2 on cell proliferation in AGS and BGC823 cells, we performed a cell proliferation assay. Cell growth curves showed that $H$. zeylanica-E2 significantly inhibited cell proliferation in AGS and BGC823 cells on day $11(p<$ $0.05)$. This marked inhibition continued to day 13 in BGC823 cells $(p<0.01)$ (Figure 8A). H. zeylanica-E2 significantly inhibited GC cell proliferation in a time-dependent manner. These findings suggest that $H$. zeylanica-E2 stimulation has a significant antiproliferative effect in AGS and BGC823 cells. 
(A)
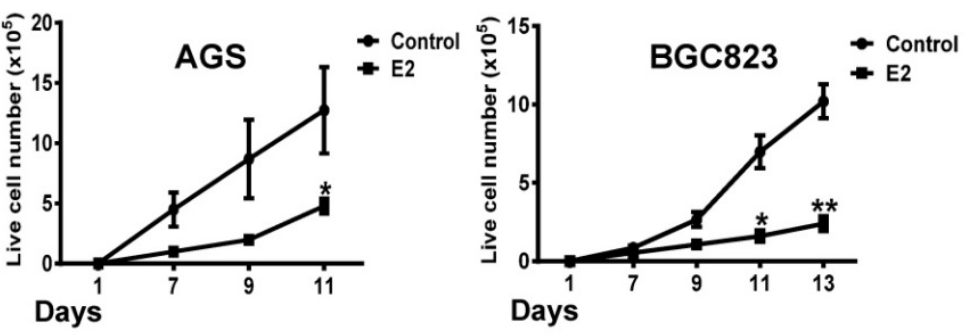

(B)

(C)
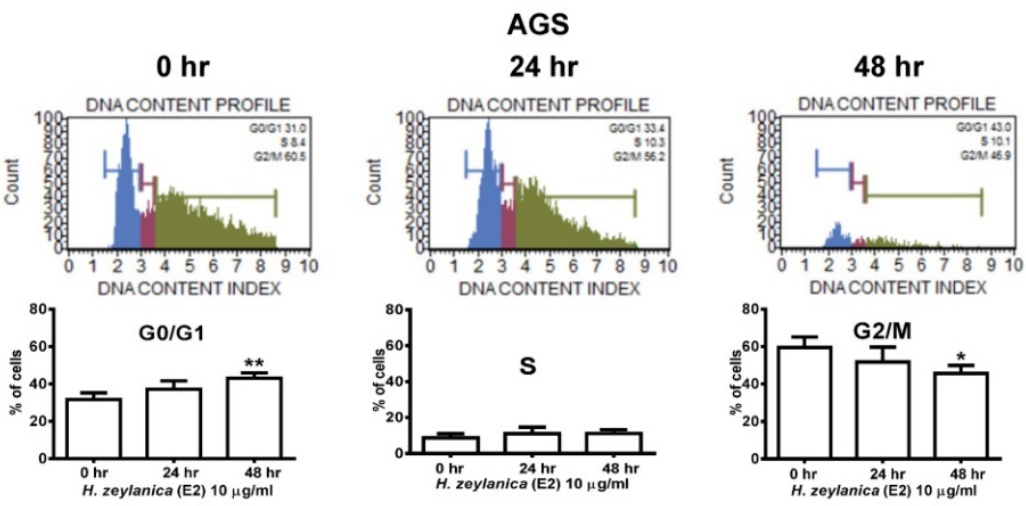

Ohr
H. zeylanica (E2)
(C) $10 \mathrm{\mu g} / \mathrm{mr}$
(C)

\section{BGC823}

$0 \mathrm{hr}$

$24 \mathrm{hr}$
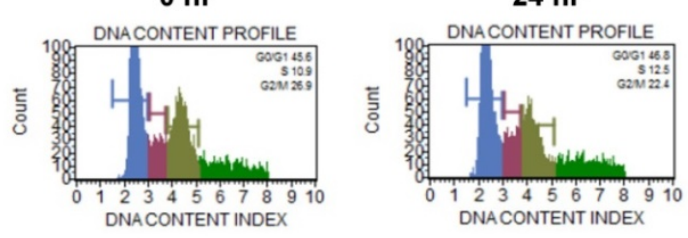

$48 \mathrm{hr}$
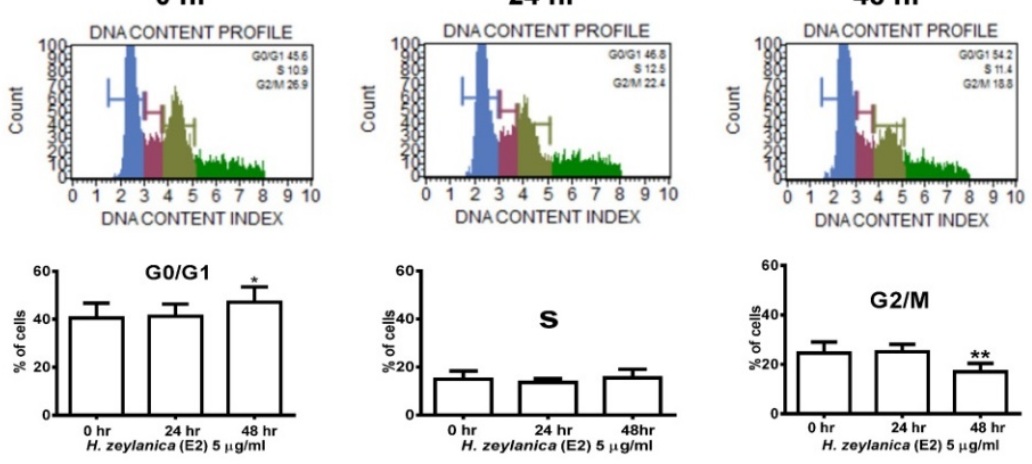

(D)

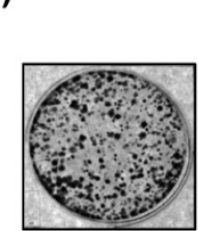

Control

(E)

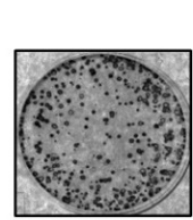

Control
AGS

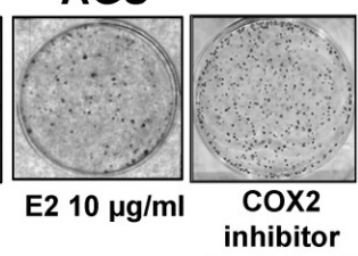

(CLC; 5 M)

BGC823

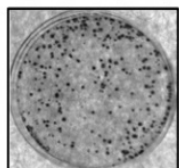

E2 $5 \mu \mathrm{g} / \mathrm{ml}$

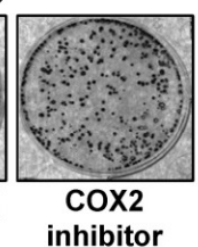

(CLC; $5 \mu \mathrm{M}$ )
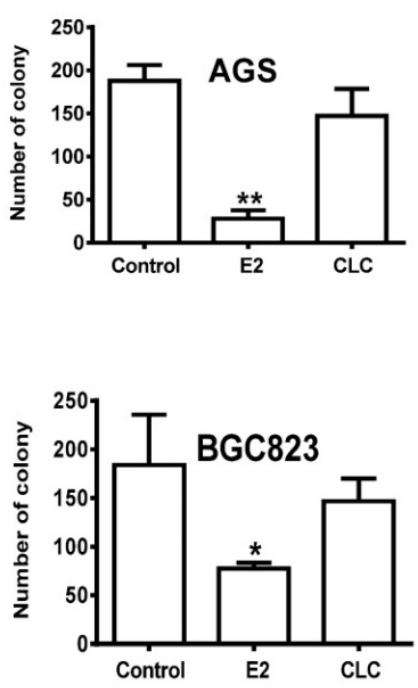

Figure 8. Effects of $\mathbf{H}$. zeylanica-E2 on GC cell proliferation, colony-forming ability, and cell cycle arrest in G0/G1 and G2/M phases. (A) AGS and BGC823 cells were treated with $\mathrm{H}$. zeylanica-E2 for various times in the colony-forming assay, and the number of cells was counted after staining with crystal violet. Each experimental 
group included five random fields for analysis. (B) AGS and (C) BGC823 cells were treated with H. zeylanica-E2 for 0, 24, or $48 \mathrm{~h}$. The cells from different experimental groups were collected and incubated with Muse ${ }^{\mathrm{TM}}$ Cell Cycle Reagent (Merck) while protected from light at room temperature for 30 min. The cell populations in each phase of the cycle (G0/G1, S, and G2/M) were analyzed using a Muse ${ }^{\mathrm{TM}}$ Cell Analyzer (Merck). (D) AGS and (E) BGC823 cells were treated with H. zeylanica-E2 or $5 \mu$ M CLC for (D) 11 or (E) 13 days, the colony-forming assay was performed, and the number of cells was counted after staining with crystal violet. Each experimental group included five random fields for analysis. Data are presented as mean \pm SEM of three independent experiments. Student's-t-test or one-way ANOVA was used for comparison with the control. $\left({ }^{*} \mathrm{p}<0.05\right.$, **p $<0.01)$.

Next, flow cytometry was performed to examine whether $H$. zeylanica-E2 affects cell cycle progression in GC cells. Compared with the control (G0/G1 phase: $31.6 \%$; G2/M phase: 59.5\%), in AGS cells, $H$. zeylanica-E2 treatment for $48 \mathrm{~h}$ significantly increased the percentage of cells in G0/G1 phase $(43.1 \%$; $p<$ 0.01 ) and reduced the percentage of cells in G2/M phase $(45.7 \% ; p<0.05)$. H. zeylanica-E2 significantly prevented cell cycle progression in AGS cells in a time-dependent manner (Figure 8B). Compared with the control (G0/G1 phase: 40.6\%; G2/M phase: $24.5 \%$ ), in BGC823 cells, $H$. zeylanica-E2 treatment for $48 \mathrm{~h}$ significantly increased the percentage of cells in G0/G1 phase to $47.2 \%(p<0.05)$ and reduced the percentage of cells in $\mathrm{G} 2 / \mathrm{M}$ phase $(17 \%, p<0.01)$ (Figure 8C). However, the percentages of cells in S phase did not change in AGS and BGC823 cells treated with $H$. zeylanica-E2 (Figure 8B, middle and Figure 8C, middle). These findings suggest that $H$. zeylanica-E2 treatment inhibited cell growth in GC cells through cell cycle arrest in G0/G1 and G2/M phases.

The entire progression of cancer cell metastasis requires the ability to enrich abilities for migration/invasion, survival, and colony formation [58]. Next, we explored the effect of $H$. zeylanica-E2 on the colony formation of GC cells. As for the cell proliferation results presented above, $H$. zeylanica-E2 treatment significantly inhibited the colony-forming ability of AGS and BGC823 cells ( 0.15 and 0.42 of the control values; $p<0.01$ and $p<0.05$, respectively). We note that the colony-forming ability was not significantly inhibited by CLC in AGS and BGC823 cells (0.78-fold, NS; 0.80-fold, NS), respectively (Figures $8 \mathrm{D}$ and $8 \mathrm{E}$ ). These findings suggest that the inhibitory effect of $H$. zeylanica-E2 on the colony-forming ability of GC cells does not involve COX-2.

\section{Possible Participation of COX-2 in $\mathrm{H}$. zeylanica-E2-Reduced AGS Cell Mobility}

The scratch wound-healing assay was performed to investigate the effects of $H$. zeylanica-E2 or CLC on the migration of AGS and BGC823 cells. AGS cells were treated with $H$. zeylanica-E2 or CLC $24 \mathrm{~h}$ after the scratch wound was induced. Compared with control cells, the wound healing rate was significantly 1.52-fold and 1.53-fold higher for E2 and CLC, respectively (both $p<0.01$ ) (Figure 9A). However, compared with the control group, these drugs did not affect the wound healing rate in BGC823 cells (Figure 9B). These data support the hypothesis that $H$. zeylanica-E2 inhibits cell migration and that this effect may involve COX-2 protein in AGS cells, but not in BGC823 cells.

To summarize our findings, we identified four in vitro antitumor activities of $H$. zeylanica-E2 in GC cells. H. zeylanica-E2 increased GC apoptosis by modulating endogenous apoptosis-associated proteins (Bcl-2, Bax, caspase $3 / 7$, cleaved PARP) and increased GC autophagy by regulating autophagyassociated proteins (ATG7, ATG5, LC3-I, and LC3-II). H. zeylanica-E2 inhibited GC cell cycle progression, which led to cell cycle arrest in G0/G1 and G2/M and suppressed GC migration. These findings lead us to conclude that the anticancer effects of $H$. zeylanica-E2 in GC cells can be partly ascribed to TNF- $\alpha$ activation of the proinflammatory CPLA2-COX-2-PGE 2 pathway. We propose that $H$. zeylanica-E2 has potential as a drug for adjunctive therapy in the treatment of GC (Figure 10).

\section{Discussion}

Chronic inflammation is considered a vital factor involved in the development and progression of GC [19]. Masami et al. have reported that $H$. pylori infection of GC cells activates the NF- $\mathrm{kB}$ pathway, which stimulates the expression of TNF- $\alpha$ and inflammatory proteins such as COX-2 and $\mathrm{PGE}_{2}[23$, 24, 59]. H. pylori infection is also related to the occurrence and progression of GC [60, 61]. In general, TNF- $\alpha$ in serum plays an important role in tumor necrosis and defense against infectious diseases. However, overexpression of TNF- $\alpha$ may induce a strong inflammatory response and organ failure, which can increase GC risk [60, 61].

Recent studies have reported that COX-2 is overexpressed in several cancers, such as colorectal cancer, HCC, GC, pancreatic cancer, and breast cancer [62-66]. Overexpression of COX-2 and MMP-13 has been reported in many clinical GC specimens and may be related to tumor invasion, metastasis, tumornode-metastasis stage, and overall survival of patients with GC. It has been suggested that COX-2 and MMP-13 may be biomarkers of GC progress [50]. Several recent studies have also reported that upregulation of COX-2 is involved in the development of $\mathrm{Hp}$-induced inflammation, which is involved in the progression from precancerous lesions 
to GC. COX-2 also promotes cell proliferation, angiogenesis, and anti-apoptosis in GC cells [24, 64, 67]. Romano et al. have shown that $H$. pylori causes the accumulation of COX-2 and $\mathrm{PGE}_{2}$ in GC [68]. Another group has also reported similar results. COX-2 overexpression leads to the accumulation of $\mathrm{PGE}_{2}$ in GC cells, where it becomes a key factor in maintaining tumor survival [69]. The public NCBI web GEO profile (ID: GDS1210/U04636) indicates that COX-2 expression is higher in GC tissues $(\mathrm{T}=22$; mean $=$ $36.44)$ than in normal control tissues $(\mathrm{N}=8$; mean $=$ 8.69) $(p<0.0011$, unpaired $t$-test). The precise roles of COX-2 in GC require further investigation.

Traditional COX inhibitors such as nonsteroidal anti-inflammatory drugs (NSAIDs) can reduce the risk of GC $[70,71]$. However, NSAIDs also have side effects such as gastric bleeding or gastric perforation because of the simultaneous inhibition of COX-1 and downstream $\mathrm{PGE}_{2}$, which lead to alterations in the gastric mucosa and may cause injury to the stomach wall [72, 73]. Therefore, it is important to develop specific COX-2 inhibitors that do not affect the performance of COX-1. COX-2-specific inhibitors include CLC and rofecoxib. anti-inflammatory COX-2 inhibitors prevent the production of COX-2 enzyme, which can cause stomach irritation and pain. Anti-inflammatory COX-2 inhibitors prevent the production of COX-2 but do not affect the production of COX-1. COX-1 protects the stomach wall [74, 75]. Traditional analgesics cannot distinguish between

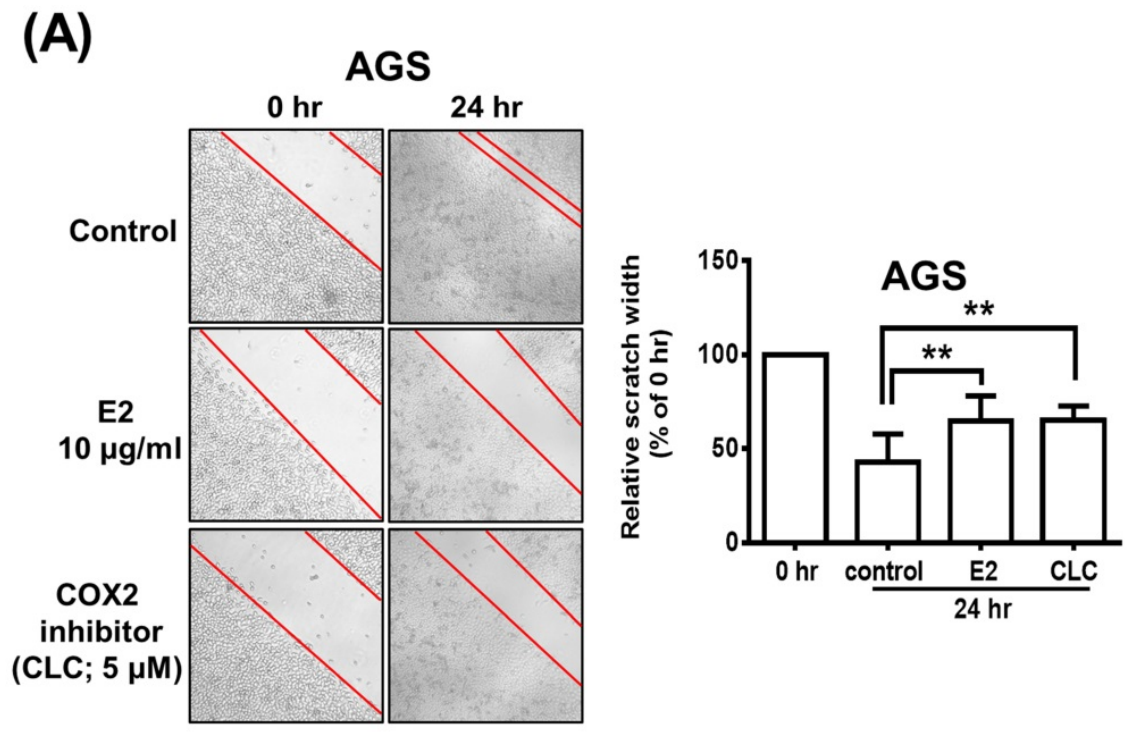

(B)

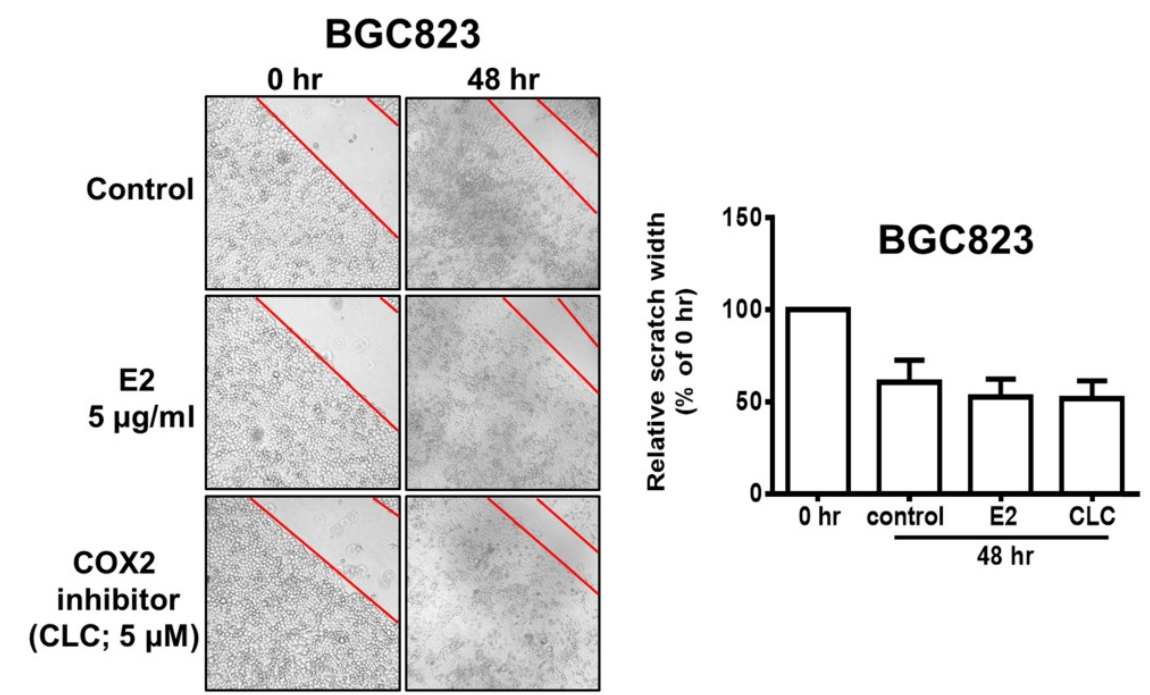

Figure 9. The role of COX-2 in H. zeylanica-E2-reduced AGS cell mobility. (A) Cell mobility was analyzed using the scratch wound-healing assay in (A) AGS cells treated with $\mathrm{H}$. zeylanica-E2 or CLC for $24 \mathrm{~h}$ and (B) BGC823 cells treated with these drugs for $48 \mathrm{~h}$. The control group was at $24 \mathrm{~h}$ or $48 \mathrm{~h}$ after scratch wound healing assay was induced and did not involve any drugs. Each experimental group included five random fields for analysis. Magnification, $\times 100$. Data are expressed as the mean \pm SEM of triplicate migration wells. Student's-t-test or one-way ANOVA was used for comparison with the control. $(* * \mathrm{p}<0.01)$. 
COX-1 and COX-2, and their use can cause stomach ulcers or bleeding. However, the use of COX-2-specific inhibitors has some contraindications. Because COX-2-specific inhibitors cannot block the production of systemic prostacyclin or inhibit thromboxane A2, these drugs may alter the balance between prothrombotic and antithrombotic activities in vivo, which may increase the risk of adverse cardiovascular events such as myocardial infarction. The European Union is amending the labeling instructions for anti-inflammatory COX-2 inhibitor drugs to strengthen the warning that these drugs can cause gastrointestinal and increase cardiovascular risk [76-78].

$H$. zeylanica has marked extensive pharmacological effects, such as hepatoprotective, anti-inflammation, antioxidation, antiosteoporosis, immunomodulatory, and neuroprotective activities [30-32, 36]. Notably, H. zeylanica exhibits striking anticancer activity in various human cancers $[79,80]$. However, the mechanisms responsible for these $H$. zeylanica anticancer actions remain unclear for GC. Therefore, we focused on evaluating whether $H$. zeylanica has anticancer effects in GC cells. Its inflammation-inhibiting effect has been confirmed repeatedly in animal experiments, and its specific anticancer mechanisms have received much attention $[81,82]$. However, there are concerns about the safety, efficacy, and the absence of reliable clinical research. Additionally, its potential medicinal properties remain unconfirmed because its use in oral therapy requires further investigation.

We analyzed $H$. zeylanica extracts (E1 and E2) using HPLC. The H. zeylanica secondary extracts from H. zeylanica-E1 and H. zeylanica-E2 were prepared, and we found that $H$. zeylanica contained mostly flavonoids compounds (the major compounds are ugonins J and K) [30-33]. We found that incubation of cells for 24 or $48 \mathrm{~h}$ with $H$. zeylanica-E1 at doses $\leq 1000$ $\mu \mathrm{g} / \mathrm{mL}$ did not significantly affect the viability of the two GC cell lines (AGS and BGC823) compared with normal GES-1 cells. Interestingly, $H$. zeylanica-E2 exhibited dose- and time-dependent effects on apoptosis in GC cells. We also found that $H$. zeylanica-E2 was selectively toxic to GC cells but had minimal or no toxicity to normal GES-1 cells. Liou et al. reported that $H$. zeylanica-E1 and $H$. zeylanica-E2 contain different compounds (two major compounds,

\section{GC cell}

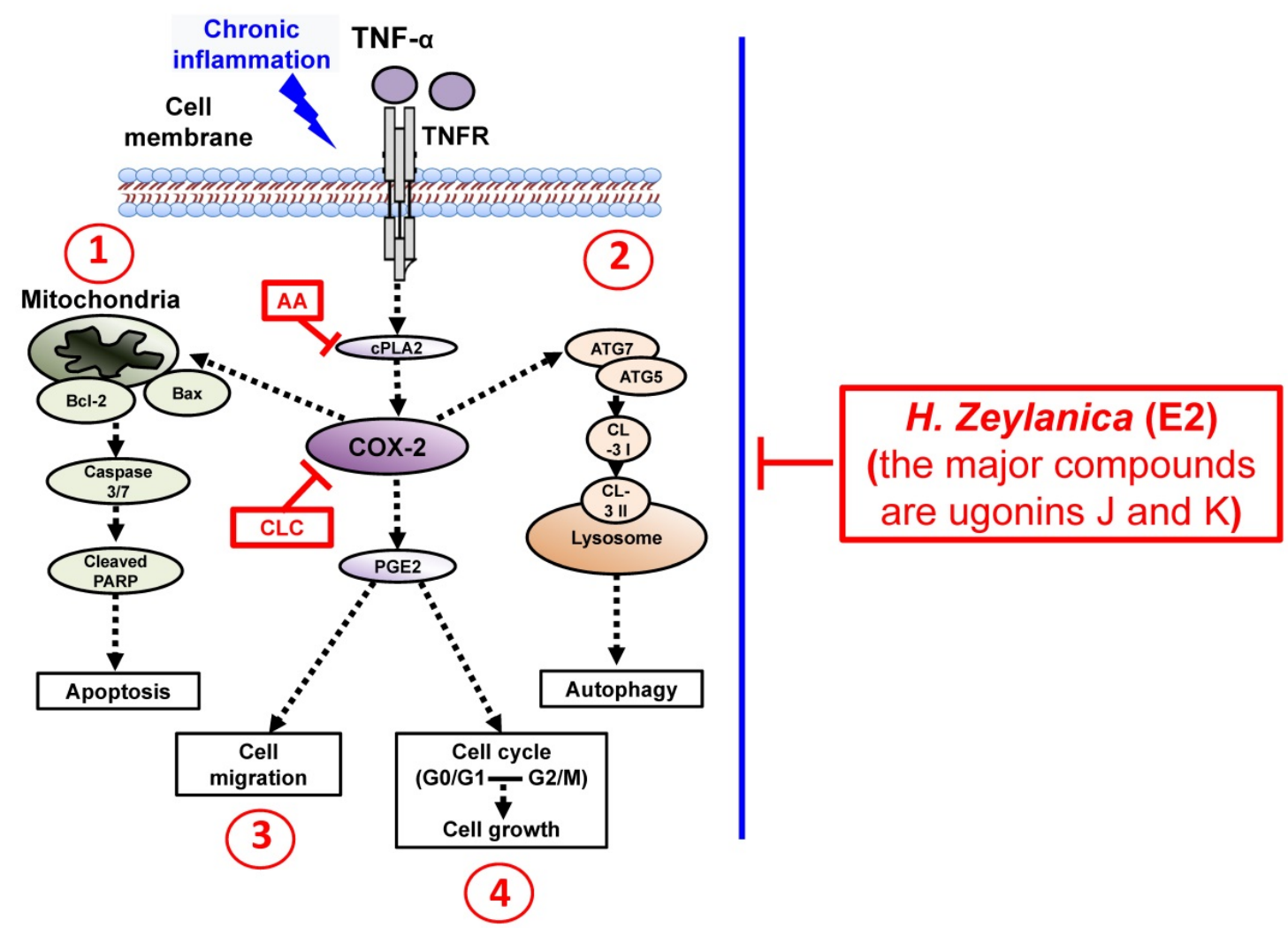

Figure 10. Schematic diagram characterizing the anticancer mechanism underlying the effects of H. zeylanica-E2 treatment in GC cells. $H$. zeylanica-E2 may increase GC apoptosis, autophagy, and cell cycle arrest, but may suppress GC migration. Apoptosis and autophagy are regulated by endogenous apoptosis-associated proteins (Bcl-2, Bax, caspase 3/7, and cleaved PARP), and autophagy-associated proteins (ATG7, ATG5, LC3-I, and LC3-II). Cell cycle arrest may occur in G0/G1 and G2/M. All of these anticancer effects may be partly ascribed to TNF- $\alpha$ activation of the proinflammatory COX-2 pathway. Taken together, these anticancer effects suggest that $H$. zeylanica-E2 has potential as a chemotherapeutic drug for the treatment of GC. 
ugonins J and K) as analyzed by HPLC [39]. In future studies, we plan to identify, isolate, and purify the bioactive compounds in $H$. zeylanica-E2 that exhibit anticancer activity induced by TNF- $\alpha$ in GC cells.

Our experimental data show the in vitro antitumor effects of $H$. zeylanica-E2 in GC cells. We found several main effects of $H$. zeylanica-E2, First, this extract increased GC apoptosis by modulating endogenous apoptosis-associated proteins such as Bcl-2, caspase 3/7, and cleaved PARP in AGS cells. This effect was time dependent, especially in late-stage apoptosis. H. zeylanica-E2 increased GC apoptosis by modulating endogenous apoptosisassociated proteins such as Bax, caspase 3/7, and cleaved PARP proteins in BGC823 cells in a time-dependent manner, especially in late-stage apoptosis. Second, H. zeylanica-E2 increased GC autophagy by regulating autophagy-associated proteins and increasing the LC3-II/LC3-I ratio. $H$. zeylanica-E2 and CLC significantly decreased the accumulation of COX-2 protein in AGS cells. Notably, the LC3-II/LC3-I ratio and ATG5 and ATG7 expression were significantly increased in BGC823 cells. CLC significantly decreased the accumulation of COX-2 protein in BGC823 cells. Third, H. zeylanica-E2 significantly inhibited GC cell cycle progression in a time-dependent manner, which led to cell cycle arrest in G0/G1 and G2/M in AGS and BGC823 cells. Fourth, $H$. zeylanica-E2 inhibited cell migration via COX-2 protein in AGS cells but not in BGC823 cells.

Differentiated GC cells form aggregated masses and colonies, which suggests that cell mobility is specific to undifferentiated GC cells. However, different two-type reactions between AGS cells and BGC823 cells with pro-apoptosis, pro-autophagy, and antimigration through different proteins interact. We suggest that the source and degree of differentiation may affect GC cells differently. Histomorphologically, GC is divided into two main types: intestinaldifferentiated and diffuse-undifferentiated [83, 84]. However, lesions with a similar type may differ in their biological aggressiveness and response to therapy. The molecular events related to the development and progression of GC also seem to differ [84]. The involvement of COX-2 activity in the tumorigenic microenvironment is poorly understood. Data from our current study provide new insights that will help to clarify the mechanisms underlying the regulation of GC tumorigenesis by COX-2. Future extensive prospective studies are warranted before COX-2 can be clinically applied as a therapeutic agent for the treatment of GC.

\section{Conclusions}

Our results demonstrated that E2, but not E1, significantly increased GC apoptosis, autophagy, and cell cycle arrest, but may suppress GC migration. Apoptosis and autophagy are regulated by endogenous apoptosis-associated proteins (Bcl-2, Bax, caspase $3 / 7$, and cleaved PARP), and autophagyassociated proteins (ATG7, ATG5, LC3-I, and LC3-II). Cell cycle arrest may occur in G0/G1 and G2/M. All of these anticancer effects may be partly ascribed to the TNF- $\alpha$-activated proinflammatory CPLA2-COX-2$\mathrm{PGE}_{2}$ pathway. Taken together, these anticancer effects suggest that $H$. zeylanica-E2 has potential as a novel adjunctive agent for the treatment of GC.

\section{Supplementary Material}

Supplementary figure.

http://www.jcancer.org/v12p7052s1.pdf

\section{Acknowledgements}

The authors thank Dr. K. H. Lin of Chang Gung University (Taiwan) to provide the AGS cell line. Additionally, Dr. Q.X Chen. and Dr. D.W. Zhou of Xiamen university (China) to provide the GES-1 and BGC823 cell lines. Dr. C. F. Lin of Chang Gung University of Science and Technology (Taiwan) to provide the $H$. zeylanica extracts.

\section{Funding}

This work was supported by grants from Ministry of Science and Technology of Taiwan (MOST 109-2320-B-255-003-MY2), Chang Gung Memorial Hospital (CMRPF1I0031, CMRPF3L0031 and BMRPD16) and Chang Gung University of Science and Technology (ZRRPF3J0081-5, ZRRPF3J0081-7, ZRRPF3K0111-6, ZRRPF3K0111-10, ZRRPF3L0091-6, ZRRPF3L0091-10 and ZMRPF3L0071).

\section{Data Availability}

The data used to support the findings of this study are included in the article.

\section{Author Contributions}

Conceived and designed the experiments, C.Y.C.; performed the experiments, H.C.L., W.J.L. and M.Y.C.; analyzed the data, H.C.L., W.J.L. and M.C.Y.; contributed reagents/materials, H.C.L., M.C.Y. and C.C.T.; writing-original draft preparation, M.M.T.; writing-review and editing, C.Y.C.; funding acquisition, M.M.T. and C.Y.C.; All the authors reviewed the results and approved the final version of the manuscript. All authors have read and agreed to the published version of the manuscript.

\section{Competing Interests}

The authors have declared that no competing interest exists. 


\section{References}

1. Siegel RL, Miller KD, Jemal A. Cancer statistics, 2019. CA: a cancer journal for clinicians. 2019; 69: 7-34

2. Wang CS, Hsieh CC, Chao TC, Jan YY, Jeng LB, Hwang TL, et al. Resectable gastric cancer: operative mortality and survival analysis. Chang Gung medical journal. 2002; 25: 216-27.

3. Chen XZ, Zhang WH, Yang K, Zhang B, Chen ZX, Chen JP, et al. Quantitative comparisons of summary receiver operating characteristics (sROC) curves among conventional serological tumor biomarkers for predicting gastric cancer in Chinese population. Tumour biology : the journal of the International Society for Oncodevelopmental Biology and Medicine. 2014; 35: 9015-22.

4. Correa P. Gastric cancer: overview. Gastroenterology clinics of North America. 2013; 42: 211-7.

5. Dassen AE, Lemmens VE, van de Poll-Franse LV, Creemers GJ, Brenninkmeijer SJ, Lips DJ, et al. Trends in incidence, treatment and survival of gastric adenocarcinoma between 1990 and 2007: a population-based study in the Netherlands. Eur J Cancer. 2010; 46: 1101-10.

6. Crew KD, Neugut AI. Epidemiology of gastric cancer. World journal of gastroenterology. 2006; 12: 354-62.

7. Wu CW, Hsiung CA, Lo SS, Hsieh MC, Chen JH, Li AF, et al. Nodal dissection for patients with gastric cancer: a randomised controlled trial. The Lancet Oncology. 2006; 7: 309-15.

8. Wu CW, Lo SS, Shen KH, Hsieh MC, Lui WY, P'Eng F K. Surgical mortality, survival, and quality of life after resection for gastric cancer in the elderly. World journal of surgery. 2000; 24: 465-72.

9. Oba K, Paoletti X, Bang YJ, Bleiberg H, Burzykowski T, Fuse N, et al. Role of chemotherapy for advanced/recurrent gastric cancer: an individual-patientdata meta-analysis. Eur J Cancer. 2013; 49: 1565-77.

10. Hsieh HL, Tsai MM. Tumor progression-dependent angiogenesis in gastric cancer and its potential application. World journal of gastrointestinal oncology. 2019; 11: 686-704.

11. Baniak N, Senger JL, Ahmed S, Kanthan SC, Kanthan R. Gastric biomarkers: a global review. World journal of surgical oncology. 2016; 14: 212.

12. Kwon CY, Lee B, Kim KI, Lee BJ. Herbal medicine on cancer-related fatigue of lung cancer survivors: Protocol for a systematic review. Medicine. 2020; 99: e18968.

13. Wang Q, Wang SF, Jiao LJ, Zhang RX, Zhong Y, Zhang J, et al. Oral Chinese herbal medicine as maintenance treatment after chemotherapy for advanced non-small-cell lung cancer: a systematic review and meta-analysis. Curr Oncol. 2017; 24: e269-e76.

14. Efferth T, Schottler U, Krishna S, Schmiedek P, Wenz F, Giordano FA. Hepatotoxicity by combination treatment of temozolomide, artesunate and Chinese herbs in a glioblastoma multiforme patient: case report review of the literature. Archives of toxicology. 2017; 91: 1833-46.

15. Wang Z, Li J, Ji Y, An P, Zhang S, Li Z. Traditional herbal medicine: a review of potential of inhibitory hepatocellular carcinoma in basic research and clinical trial. Evidence-based complementary and alternative medicine : eCAM. 2013; 2013: 268963.

16. Shi Z, Song T, Wan Y, Xie J, Yan Y, Shi K, et al. A systematic review and meta-analysis of traditional insect Chinese medicines combined chemotherapy for non-surgical hepatocellular carcinoma therapy. Scientific reports. 2017; 7: 4355.

17. Lee YK, Bae K, Yoo HS, Cho SH. Benefit of Adjuvant Traditional Herbal Medicine With Chemotherapy for Resectable Gastric Cancer. Integrative cancer therapies. 2018; 17: 619-27.

18. Wang T, Fu X, Wang Z. Danshen Formulae for Cancer: A Systematic Review and Meta-Analysis of High-Quality Randomized Controlled Trials. Evidence-based complementary and alternative medicine : eCAM. 2019; 2019: 2310639.

19. Camargo MC, Mera R, Correa P, Peek RM, Jr., Fontham ET, Goodman KJ, et al. Interleukin-1beta and interleukin-1 receptor antagonist gene polymorphisms and gastric cancer: a meta-analysis. Cancer epidemiology, biomarkers \& prevention : a publication of the American Association for Cancer Research, cosponsored by the American Society of Preventive Oncology. 2006; 15: 1674-87.

20. Barreto-Zuniga R, Maruyama M, Kato Y, Aizu K, Ohta H, Takekoshi T, et al. Significance of Helicobacter pylori infection as a risk factor in gastric cancer: serological and histological studies. Journal of gastroenterology. 1997; 32: 289-94.

21. Luo JL, Kamata H, Karin M. IKK/NF-kappaB signaling: balancing life and death--a new approach to cancer therapy. The Journal of clinical investigation. 2005; 115: 2625-32.

22. Tak PP, Firestein GS. NF-kappaB: a key role in inflammatory diseases. The Journal of clinical investigation. 2001; 107: 7-11.

23. Suganuma M, Watanabe T, Yamaguchi K, Takahashi A, Fujiki H. Human gastric cancer development with TNF-alpha-inducing protein secreted from Helicobacter pylori. Cancer letters. 2012; 322: 133-8.

24. Macarthur M, Hold GL, El-Omar EM. Inflammation and Cancer II. Role of chronic inflammation and cytokine gene polymorphisms in the pathogenesis of gastrointestinal malignancy. American journal of physiology Gastrointestinal and liver physiology. 2004; 286: G515-20.

25. Rasmussen SJ, Eckmann L, Quayle AJ, Shen L, Zhang YX, Anderson DJ, et al. Secretion of proinflammatory cytokines by epithelial cells in response to
Chlamydia infection suggests a central role for epithelial cells in chlamydial pathogenesis. The Journal of clinical investigation. 1997; 99: 77-87.

26. Iizasa H, Nanbo A, Nishikawa J, Jinushi M, Yoshiyama H. Epstein-Barr Virus (EBV)-associated gastric carcinoma. Viruses. 2012; 4: 3420-39.

27. Kim KM, Kwon MS, Hong SJ, Min KO, Seo EJ, Lee KY, et al. Genetic classification of intestinal-type and diffuse-type gastric cancers based on chromosomal loss and microsatellite instability. Virchows Archiv : an international journal of pathology. 2003; 443: 491-500.

28. Yasui W, Oue N, Kuniyasu H, Ito R, Tahara E, Yokozaki H. Molecular diagnosis of gastric cancer: present and future. Gastric cancer : official journal of the International Gastric Cancer Association and the Japanese Gastric Cancer Association. 2001; 4: 113-21.

29. Kipanyula MJ, Seke Etet PF, Vecchio L, Farahna M, Nukenine EN, Nwabo Kamdje AH. Signaling pathways bridging microbial-triggered inflammation and cancer. Cellular signalling. 2013; 25: 403-16.

30. Huang YC, Hwang TL, Chang CS, Yang YL, Shen CN, Liao WY, et al. Anti-inflammatory flavonoids from the rhizomes of Helminthostachys zeylanica. Journal of natural products. 2009; 72: 1273-8

31. Huang YL, Yeh PY, Shen CC, Chen CC. Antioxidant flavonoids from the rhizomes of Helminthostachys zeylanica. Phytochemistry. 2003; 64: 1277-83.

32. Huang YC, Hwang TL, Yang YL, Wu SH, Hsu MH, Wang JP, et al. Acetogenin and prenylated flavonoids from Helminthostachys zeylanica with inhibitory activity on superoxide generation and elastase release by neutrophils. Planta medica. 2010; 76: 447-53.

33. Chen CY, Liaw CC, Chen YH, Chang WY, Chung PJ, Hwang TL. A novel immunomodulatory effect of ugonin $U$ in human neutrophils via stimulation of phospholipase C. Free radical biology \& medicine. 2014; 72: 222-31.

34. Cao L, Li R, Chen $\mathrm{X}$, Xue $\mathrm{Y}$, Liu D. Neougonin A Inhibits Lipopolysaccharide-Induced Inflammatory Responses via Downregulation of the NF-kB Signaling Pathway in RAW 264.7 Macrophages. Inflammation. 2016; 39: 1939-48.

35. Wu KC, Huang SS, Kuo YH, Ho YL, Yang CS, Chang YS, et al. Ugonin M, a Helminthostachys zeylanica Constituent, Prevents LPS-Induced Acute Lung Injury through TLR4-Mediated MAPK and NF-kappaB Signaling Pathways. Molecules. 2017; 22

36. Yang CM, Yang SH, Lee TH, Fang JY, Lin CF, Jou MJ, et al. Evaluation of Anti-Inflammatory Effects of Helminthostachys zeylanica Extracts via Inhibiting Bradykinin-Induced MMP-9 Expression in Brain Astrocytes. Molecular neurobiology. 2016; 53: 5995-6005.

37. Su LH, Li YP, Li HM, Dai WF, Liu D, Cao L, et al. Anti-inflammatory Prenylated Flavonoids from Helminthostachys zeylanica. Chemical \& pharmaceutical bulletin. 2016; 64: 497-501.

38. Suja SR, Latha PG, Pushpangadan P, Rajasekharan S. Evaluation of hepatoprotective effects of Helminthostachys zeylanica (L.) Hook against carbon tetrachloride-induced liver damage in Wistar rats. Journal of ethnopharmacology. 2004; 92: 61-6.

39. Liou CJ, Huang YL, Huang WC, Yeh KW, Huang TY, Lin CF. Water extract of Helminthostachys zeylanica attenuates LPS-induced acute lung injury in mice by modulating NF-kappaB and MAPK pathways. Journal of ethnopharmacology. 2017; 199: 30-8.

40. Lee KF, Tsai MM, Tsai CY, Huang CG, Ou YH, Hsieh CC, et al. DEK Is a Potential Biomarker Associated with Malignant Phenotype in Gastric Cancer Tissues and Plasma. International journal of molecular sciences. 2019; 20.

41. Tsai MM, Wang CS, Tsai CY, Chen CY, Chi HC, Tseng YH, et al. MicroRNA-196a/-196b promote cell metastasis via negative regulation of radixin in human gastric cancer. Cancer letters. 2014; 351: 222-31.

42. Tsai MM, Huang HW, Wang CS, Lee KF, Tsai CY, Lu PH, et al. MicroRNA-26b inhibits tumor metastasis by targeting the KPNA2/c-jun pathway in human gastric cancer. Oncotarget. 2016; 7: 39511-26.

43. Cheng CY, Haque A, Hsieh MF, Imran Hassan S, Faizi MSH, Dege N, et al. 1,4-Disubstituted 1H-1,2,3-Triazoles for Renal Diseases: Studies of Viability, Anti-Inflammatory, and Antioxidant Activities. International journal of molecular sciences. 2020; 21.

44. Tsai MM, Lin PY, Cheng WL, Tsai CY, Chi HC, Chen CY, et al. Overexpression of ADP-ribosylation factor 1 in human gastric carcinoma and its clinicopathological significance. Cancer science. 2012; 103: 1136-44.

45. Lee IT, Lin CF, Huang YL, Chong KY, Hsieh MF, Huang TH, et al. Protective mechanisms of resveratrol derivatives against TNF-alpha-induced inflammatory responses in rat mesangial cells. Cytokine. 2019; 113: 380-92.

46. Chi HC, Chen SL, Cheng YH, Lin TK, Tsai CY, Tsai MM, et al. Chemotherapy resistance and metastasis-promoting effects of thyroid hormone in hepatocarcinoma cells are mediated by suppression of FoxO1 and Bim pathway. Cell death \& disease. 2016; 7: e2324.

47. Tseng YH, Huang YH, Lin TK, Wu SM, Chi HC, Tsai CY, et al. Thyroid hormone suppresses expression of stathmin and associated tumor growth in hepatocellular carcinoma. Scientific reports. 2016; 6: 38756.

48. Hamzehlou S, Momeny M, Zandi Z, Kashani B, Yousefi H, Dehpour AR, et al. Anti-tumor activity of neratinib, a pan-HER inhibitor, in gastric adenocarcinoma cells. European journal of pharmacology. 2019; 863: 172705 .

49. Cheng WL, Tsai MM, Tsai CY, Huang YH, Chen CY, Chi HC, et al. Glyoxalase-I is a novel prognosis factor associated with gastric cancer progression. PloS one. 2012; 7: e34352.

50. Ren J, Liu J, Sui X. Correlation of COX-2 and MMP-13 expressions with gastric cancer and their effects on prognosis. Journal of BUON : official journal of the Balkan Union of Oncology. 2019; 24: 187-93. 
51. Cheng J, Fan XM. Role of cyclooxygenase-2 in gastric cancer development and progression. World journal of gastroenterology. 2013; 19: 7361-8.

52. Wong BC, Jiang X, Fan XM, Lin MC, Jiang SH, Lam SK, et al. Suppression of RelA/p65 nuclear translocation independent of IkappaB-alpha degradation by cyclooxygenase-2 inhibitor in gastric cancer. Oncogene. 2003; 22: 1189-97.

53. Echizen K, Hirose O, Maeda Y, Oshima M. Inflammation in gastric cancer: Interplay of the COX-2/prostaglandin E2 and Toll-like receptor/MyD88 pathways. Cancer science. 2016; 107: 391-7.

54. Targosz A, Brzozowski T, Pierzchalski P, Szczyrk U, Ptak-Belowska A, Konturek SJ, et al. Helicobacter pylori promotes apoptosis, activates cyclooxygenase (COX)-2 and inhibits heat shock protein HSP70 in gastric cancer epithelial cells. Inflammation research : official journal of the European Histamine Research Society [et al]. 2012; 61: 955-66.

55. Konturek PC, Konturek SJ, Bielanski W, Kania J, Zuchowicz M, Hartwich A, et al. Influence of COX-2 inhibition by rofecoxib on serum and tumor progastrin and gastrin levels and expression of PPARgamma and apoptosis-related proteins in gastric cancer patients. Digestive diseases and sciences. 2003; 48: 2005-17.

56. Oshima H, Ishikawa T, Yoshida GJ, Naoi K, Maeda Y, Naka K, et al. TNF-alpha/TNFR1 signaling promotes gastric tumorigenesis through induction of Noxo1 and Gna14 in tumor cells. Oncogene. 2014; 33: 3820-9.

57. Sobolewski C, Cerella C, Dicato M, Ghibelli L, Diederich M. The role of cyclooxygenase-2 in cell proliferation and cell death in human malignancies. International journal of cell biology. 2010; 2010: 215158.

58. Valastyan S, Weinberg RA. Tumor metastasis: molecular insights and evolving paradigms. Cell. 2011; 147: 275-92

59. Cao HJ, Fang Y, Zhang X, Chen WJ, Zhou WP, Wang H, et al. Tumor metastasis and the reciprocal regulation of heparanase gene expression by nuclear factor kappa B in human gastric carcinoma tissue. World J Gastroenterol. 2005; 11: 903-7.

60. Luo J-L, Kamata H, Karin M. IKK/NF-KB signaling: balancing life and death a new approach to cancer therapy. The Journal of Clinical Investigation. 2005; 115: 2625-32.

61. Tak PP, Firestein GS. NF-kB: a key role in inflammatory diseases. Journal of Clinical Investigation. 2001; 107: 7-11.

62. Eberhart CE, Coffey RJ, Radhika A, Giardiello FM, Ferrenbach S, DuBois RN. Up-regulation of cyclooxygenase 2 gene expression in human colorectal adenomas and adenocarcinomas. Gastroenterology. 1994; 107: 1183-8.

63. Koga H, Sakisaka S, Ohishi M, Kawaguchi T, Taniguchi E, Sasatomi K, et al. Expression of cyclooxygenase-2 in human hepatocellular carcinoma: relevance to tumor dedifferentiation. Hepatology. 1999; 29: 688-96.

64. Ristimäki A, Honkanen N, Jänkälä H, Sipponen P, Härkönen M. Expression of Cyclooxygenase-2 in Human Gastric Carcinoma. Cancer Research. 1997; 57: 1276.

65. Tucker ON, Dannenberg AJ, Yang EK, Zhang F, Teng L, Daly JM, et al. Cyclooxygenase-2 expression is up-regulated in human pancreatic cancer. Cancer Res. 1999; 59: 987-90.

66. Hwang D, Byrne J, Scollard D, Levine E. Expression of Cyclooxygenase-1 and Cyclooxygenase-2 in Human Breast Cancer. JNCI: Journal of the National Cancer Institute. 1998; 90: 455-60.

67. Nardone G, Rocco A, Vaira D, Staibano S, Budillon A, Tatangelo F, et al. Expression of COX-2, mPGE-synthase1, MDR-1 (P-gp), and Bcl-xL: a molecular pathway of $\mathrm{H}$ pylori-related gastric carcinogenesis. J Pathol. 2004; 202: 305-12.

68. Romano M, Ricci V, Memoli A, Tuccillo C, Di Popolo A, Sommi P, et al Helicobacter pylori up-regulates cyclooxygenase-2 mRNA expression and prostaglandin E2 synthesis in MKN 28 gastric mucosal cells in vitro. J Biol Chem. 1998; 273: 28560-3.

69. Gandhi J, Khera L, Gaur N, Paul C, Kaul R. Role of Modulator of Inflammation Cyclooxygenase-2 in Gammaherpesvirus Mediated Tumorigenesis. Frontiers in Microbiology. 2017; 8: 538.

70. Wang WH, Huang JQ, Zheng GF, Lam SK, Karlberg J, Wong BC Non-steroidal anti-inflammatory drug use and the risk of gastric cancer: a systematic review and meta-analysis. J Natl Cancer Inst. 2003; 95: 1784-91.

71. Koeberle A, Werz O. Perspective of microsomal prostaglandin E2 synthase-1 as drug target in inflammation-related disorders. Biochemical pharmacology. 2015; 98 : 1-15.

72. Harbison SP, Dempsey DT. Peptic ulcer disease. Curr Probl Surg. 2005; 42: 346-454.

73. Konturek PC, Konturek SJ, Pierzchalski P, Bielanski W, Duda A, Marlicz K, et al. Cancerogenesis in Helicobacter pylori infected stomach--role of growth factors, apoptosis and cyclooxygenases. Medical science monitor: international medical journal of experimental and clinical research. 2001; 7: 1092-107.

74. Ebert AD, Bartley J, David M. Aromatase inhibitors and cyclooxygenase-2 (COX-2) inhibitors in endometriosis: new questions--old answers? European journal of obstetrics, gynecology, and reproductive biology. 2005; 122: 144-50.

75. Husain SS, Szabo IL, Tamawski AS. NSAID inhibition of GI cancer growth: clinical implications and molecular mechanisms of action. The American journal of gastroenterology. 2002; 97: 542-53.

76. Datto C, Hellmund R, Siddiqui MK. Efficacy and tolerability of naproxen/esomeprazole magnesium tablets compared with non-specific NSAIDs and COX-2 inhibitors: a systematic review and network analyses. Open access rheumatology : research and reviews. 2013; 5: 1-19.

77. Heim HK, Broich K. Selective COX-2 inhibitors and risk of thromboembolic events - regulatory aspects. Thrombosis and haemostasis. 2006; 96: 423-32.
78. Chakraborti AK, Garg SK, Kumar R, Motiwala HF, Jadhavar PS. Progress in COX-2 inhibitors: a journey so far. Current medicinal chemistry. 2010; 17: 1563-93.

79. Nandakumar V, Singh T, Katiyar SK. Multi-targeted prevention and therapy of cancer by proanthocyanidins. Cancer letters. 2008; 269: 378-87.

80. Dai Q, Shu XO, Jin F, Potter JD, Kushi LH, Teas J, et al. Population-based case-control study of soyfood intake and breast cancer risk in Shanghai. British journal of cancer. 2001; 85: 372-8.

81. Huang H, Xie H, Pan Y, Zheng K, Xia Y, Chen W. Plumbagin Triggers ER Stress-Mediated Apoptosis in Prostate Cancer Cells via Induction of ROS. Cellular physiology and biochemistry : international journal of experimental cellular physiology, biochemistry, and pharmacology. 2018; 45: 267-80.

82. Jamal MS, Parveen S, Beg MA, Suhail M, Chaudhary AG, Damanhouri GA, et al. Anticancer compound plumbagin and its molecular targets: a structural insight into the inhibitory mechanisms using computational approaches. PloS one. 2014; 9: e87309.

83. Lauren P. Histogenesis of intestinal and diffuse types of gastric carcinoma. Scand J Gastroenterol Suppl. 1991; 180: 160-4.

84. Tahara E. Molecular mechanism of stomach carcinogenesis. Journal of cancer research and clinical oncology. 1993; 119: 265-72. 